\title{
Central Nervous System Regenerative Failure: Role of Oligodendrocytes, Astrocytes, and Microglia
}

\author{
Jerry Silver ${ }^{1}$, Martin E. Schwab ${ }^{2}$, and Phillip G. Popovich ${ }^{3}$ \\ ${ }^{1}$ Department of Neurosciences, Case Western Reserve University, Cleveland, Ohio 44140 \\ ${ }^{2}$ Brain Research Institute, University of Zurich and Department of Health Sciences and Technology, \\ ETH Zurich, 8057 Zurich, Switzerland \\ ${ }^{3}$ Center for Brain and Spinal Cord Repair, Ohio State University, Columbus, Ohio 43210 \\ Correspondence: phillip.popovich@osumc.edu
}

\begin{abstract}
Animal studies are now showing the exciting potential to achieve significant functional recovery following central nervous system (CNS) injury by manipulating both the inefficient intracellular growth machinery in neurons, as well as the extracellular barriers, which further limit their regenerative potential. In this review, we have focused on the three major glial cell types: oligodendrocytes, astrocytes, and microglia/macrophages, in addition to some of their precursors, which form major extrinsic barriers to regrowth in the injured CNS. Although axotomized neurons in the CNS have, at best, a limited capacity to regenerate or sprout, there is accumulating evidence that even in the adult and, especially after boosting their growth motor, neurons possess the capacity for considerable circuit reorganization and even lengthy regeneration when these glial obstacles to neuronal regrowth are modified, eliminated, or overcome.
\end{abstract}

$\mathrm{T}^{\mathrm{h}}$ he failure of injured central nervous system (CNS) axons to regenerate over long distances and reestablish connections interrupted by traumatic lesions has been known for a very long time. As early as 1890 , the striking difference between central axons and the often well-regenerating peripheral nerves was experimentally studied; peripheral nerve grafts were implanted into different parts of the brain, retina, and spinal cord. The results showed that denervated peripheral nerves are excellent growth-promoting substrates for regenerating axons, whether of peripheral or central origin. Santiago Ramón y Cajal summarized these pioneering studies in his seminal book, Regeneration and Degeneration of the Nervous System (1913 in Spanish; 1928 first English edition; Ramón y Cajal et al. 1991). He concluded that adult central neurons can be induced to grow long axons by attractive and trophic factors originating from peripheral nerves. He also speculated that the absence of regeneration in CNS tissue would be because of a lack of such factors in the adult brain and spinal cord. Modern tracing

Editors: Ben A. Barres, Marc R. Freeman, and Beth Stevens

Additional Perspectives on Glia available at www.cshperspectives.org

Copyright (C) 2015 Cold Spring Harbor Laboratory Press; all rights reserved; doi: 10.1101/cshperspect.a020602

Cite this article as Cold Spring Harb Perspect Biol 2015;7:a020602 
J. Silver et al.

methods and electron microscopy confirmed the old findings in the early 1980s (Aguayo et al. 1991), but the discovery of neurotrophic activities, for example, brain-derived neurotrophic factor (BDNF), ciliary neurotrophic factor (CNTF), or leukemia inhibitory factor (LIF), in adult CNS tissue reopened the question about molecular mechanisms. In vitro studies on the interaction of neurons confronted with CNS tissue explants or frozen sections led to a new concept of specific neurite growth inhibitory factors in the adult CNS (Schwab and Thoenen 1985; Carbonetto et al. 1987; Schwab and Caroni 1988; Fawcett et al. 1989; Rudge and Silver 1990; Mckeon et al. 1991). Surprisingly, these factors were enriched in CNS myelin and oligodendrocytes, but also in scar areas and, as found later, in perineuronal nets (PNNs) (Schwab and Caroni 1988; Sandvig et al. 2004; Pizzorusso et al. 2006; Cregg et al. 2014). Today, a detailed picture on growth inhibitory and repulsive factors expressed by different types of glial and neuronal cells at various stages of CNS development and maturation arises (Lutz and Barres 2014; Silver and Silver 2014). This article summarizes the contributions of astrocytes, oligodendrocytes, and microglia/macrophages, as well as some of their precursors to growth inhibition and regeneration failure in the adult CNS.

Although glial cells influence the growth of regenerating axons by soluble factors or membrane contacts at the level of growth cones, their influence can also regulate the growth state and programs of neurons at the transcriptional and posttranscriptional levels. Microglia and monocyte-derived macrophages (MDMs) recruited into lesioned tissue are expected to exert similar effects on axons. Thus, "extrinsic" growth regulatory cues interact with and codetermine the "intrinsic" ability of injured CNS neurons to form regenerating sprouts and elongate over long distances. Current experimental therapeutic approaches in animal models aim at manipulating all of these components, for instance, by suppressing or neutralizing growth inhibitory signals, supplying growth promoters, and enhancing neuron intrinsic growth programs (Cafferty et al. 2008; Zorner and Schwab 2010; Hollis and Tuszynski 2011; Liu et al. 2011).

\section{OLIGODENDROCYTES AND CNS MYELIN INHIBIT NEURITE REGENERATION, COMPENSATORY GROWTH, AND PLASTICITY}

\section{Adult CNS Myelin Is Inhibitory for Neurite Growth and Regeneration}

When growing dorsal root ganglion, cortical or cerebellar neurons derived from perinatal rats and mice were confronted in culture with optic nerve explants, white matter, CNS myelin, or oligodendrocytes, growth cones collapsed shortly after contact and neurite elongation stopped (Schwab and Thoenen 1985; Carbonetto et al. 1987; Schwab and Caroni 1988; Fawcett et al. 1989). Clinical and experimental observations suggested that the repair capacity of the CNS after injuries is much higher during development than at more mature stages. Using in vivo lesion experiments in embryonic chicken and newborn rodents, the switch from a regeneration-permissive to a nonpermissive property of CNS tissue seemed to be correlated in time and space with myelin formation (Reh and Kalil 1982; Keirstead et al. 1992). For a more detailed analysis of such effects, neurite growth inhibition, antiadhesive effects, and growth cone collapse were subsequently used to characterize and purify the main factors responsible for the fiber growth inhibitory effects of the adult CNS tissue. In line with the observations from the in vitro encounter assays, potent neurite growth inhibitory factors were found to be enriched in CNS myelin. The membrane proteins Nogo-A, myelin-associated glycoprotein (MAG) and oligodendrocyte/myelin glycoprotein (OMgp), the ephrins $\mathrm{B} 3$ and $\mathrm{A} 3$, the semaphorins $4 \mathrm{D}, 5 \mathrm{~A}$, and $3 \mathrm{~F}$, as well as chondroitin sulfate proteoglycans (CSPGs) and the myelin glycolipid sulfatide were all found to exert strong growth inhibitory effects on an variety of neuronal cells in vitro (Sandvig et al. 2004; Giger et al. 2010; Fawcett et al. 2012). The molecules are active at very low concentrations, which prompted the search for corresponding receptors. Today, the Nogo receptor family, NgR 1-3, the new Nogo-A-specific receptor sphingosine-1-phosphate receptor 2 (S1PR2), several Eph receptors, semaphorin receptors, and the CSPG-interacting proteins 
LAR and protein tyrosine phosphatase PTPase$\sigma$ have been identified as functional receptors mediating growth cone collapse and growth inhibition of the corresponding ligands (Liu et al. 2006a,b; Shen et al. 2009; Giger et al. 2010; Fisher et al. 2011; Kempf 2014). Like neurotrophins or Wnt, many of the growth inhibitory ligands seem to function by activation of multisubunit receptor complexes (Schwab 2010).

Specific Growth Inhibitory Factors Acting via Neuronal Receptor Complexes Are Present in the CNS and Enriched in Myelin

Two main effects can be distinguished when growing neurites interact with growth inhibitory factors: (1) a fast local collapse of lamellipodia and filopodia of the growth cones after contact with many of the inhibitory factors, and (2) long-lasting cell-body-mediated growth inhibition, for example, by Nogo-A (Nash et al. 2009; Schwab 2010). Growth cone collapse is largely mediated by effects on the cytoskeleton, in particular, in the form of actin filament destabilization (Nash et al. 2009). Activation of the small GTPase signal transducer Rho, of the downstream Rho-associated protein kinase (ROCK), and actin regulators slingshot and cofilin seem to play major roles for Nogo-A-induced inhibition. For ephrins and Nogo-A, endocytotic uptake of ligand/receptor complexes, followed by retrograde transport to neuronal cell bodies in signaling endosomes, has been shown (Zimmer et al. 2003; Joset et al. 2010). For Nogo-A, Rho-A activation and cAMP-response element-binding (CREB) inactivation play crucial roles for the subsequent long-term down-regulation of the neuronal growth machinery (Hannila and Filbin 2008; Joset et al. 2010). Accordingly, these inhibitory effects of Nogo-A, MAG, or CNS myelin can be counteracted by elevated levels of cAMP or high concentrations of neurotrophic factors, which, in turn, elevate cAMP and PCREB (Hannila and Filbin 2008). Interestingly, Nogo-A also down-regulates a potent cellular growth regulator, mammalian target of rapamycin (mTOR) (Peng et al. 2011). Conversely, exogenous stimulation of mTOR, either through the use of genetic tools or pharmacologically (e.g., by rapamycin), leads to strong stimulation of sprouting and growth, even on inhibitory substrates in vitro or in vivo (Liu et al. 2011). Whether different growth inhibitory factors converge on signaling pathways, leading to growth cone collapse or cell-body-mediated growth suppression, remains to be analyzed. A first example for such a convergence is shown by the recent demonstration that the Nogo/MAG/OMgp receptor, $\mathrm{NgR} 1$, can also function as a receptor for the structurally very different growth inhibitory CSPGs (Dickendesher et al. 2012).

Myelin-Associated Growth Inhibitors Restrict Developmental Plasticity and Stabilize the Structure of the Adult CNS

The growth inhibitory nature of CNS myelin and the expression of several different growth inhibitory factors by oligodendrocytes and in myelin membranes was a surprising finding at first. During development, many of these factors are expressed by different cell types, including subpopulations of neurons, and they serve repulsive, negative guidance functions, or antiadhesive or migration modulatory roles (Schwab 2010). Myelin formation in the CNS is tract dependent; it starts in a given fiber tract after the axons have reached their targets and established functional connections. Restricting any further growth and axonal branching in such a tract may be one of the important functions of myelinassociated growth inhibitory factors. A number of findings support this concept. Structural plasticity is very low in white matter, but higher in gray matter in the adult CNS, and highly plastic regions are often particularly low in myelin content. In the neocortex, a temporal coincidence exists between myelin formation in layers IV-VI and the maturation-dependent reduction of plasticity, for example, the closure of the critical window for ocular dominance plasticity (McGee et al. 2006). Importantly, developmental levels of structural plasticity could be reestablished in full adult life in Nogo or Nogo receptor (NgR1) knockout (KO) mice in the visual and the sensorimotor cortex (McGee et al. 2006; Akbik et al. 2013). Similar results were obtained by enzymatic removal of 
J. Silver et al.

CSPGs (Pizzorusso et al. 2006). Furthermore, aberrant sprouting was observed after experimental or pathologic demyelination, for example, in the optic nerve (Tansey et al. 1985; Colello and Schwab 1994; Phokeo et al. 2002). Neurite growth inhibitory factors expressed by oligodendrocytes, including Nogo-A and CSPGs, therefore, appear as specific stabilizers of the highly complex structure and wiring of the CNS of higher vertebrates (Fig. 1).

Suppression of Neurite Growth Inhibitory Factors Enhances Sprouting and Regeneration of Injured Neurites and Functional Recovery after CNS Injury

A variety of methods has been used to neutralize or delete myelin-associated inhibitory factors to study axonal regeneration and repair processes after CNS injury. The most extensive literature exists for Nogo-A, for which function- blocking antibodies or autoimmunizations, Nogo receptor-blocking peptides or fusion proteins, gene knockdowns (KOs), or receptor KOs have been used for in vivo manipulations, in particular, in the context of spinal cord injury (SCI), stroke studies, as well as autoimmune disease models (Schwab 2004; Cafferty et al. 2008; Pernet and Schwab 2012). Acute blockade of Nogo-A, the Nogo receptor complex, or of the downstream Rho/ROCK pathway led to enhanced regenerative sprouting and elongation over variable distances of injured corticospinal, rubrospinal, or aminergic axons in the spinal cord of adult rats and mice after injury. Enhanced compensatory sprouting of spared fibers is often also observed. On the level of behavior, animals frequently show significantly higher levels of functional recovery than the control reagent-treated or -untreated controls. Negative effects, which could be expected if undirected or random growth was overstimulated,

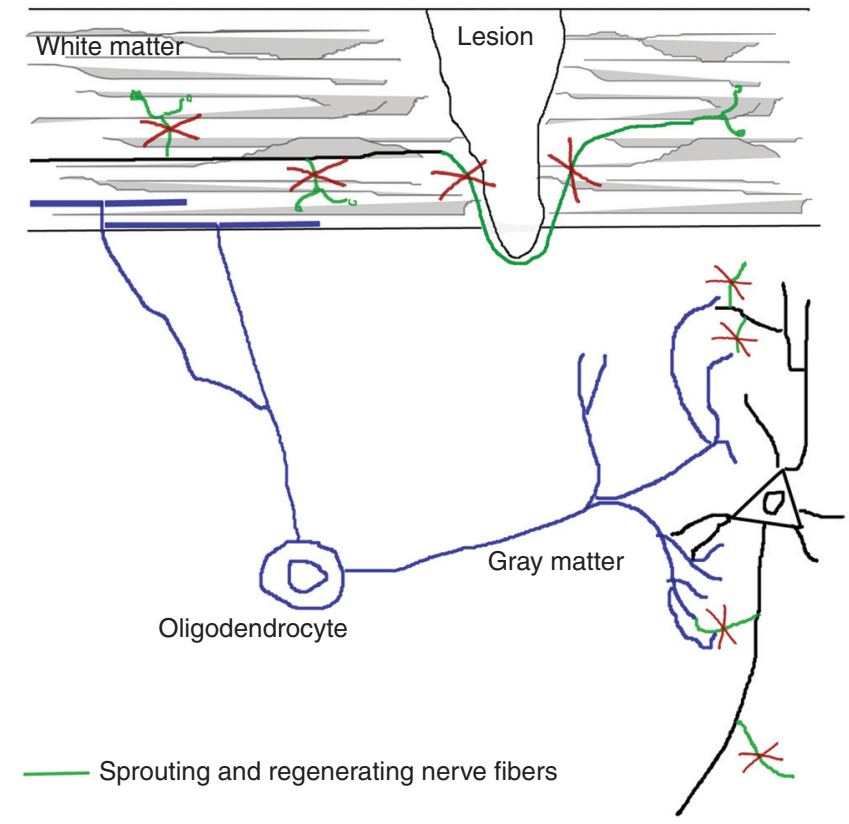

Figure 1. Oligodendrocytes express neurite growth inhibitory proteins, including the membrane protein NogoA, on their cell surface and CNS myelin. These proteins inhibit branch formation along the mature axon in white matter, but they also impair compensatory and regenerative fiber growth following axonal injury. In gray matter, the lower levels of these inhibitory proteins allow some structural remodeling of dendritic and axonal arbors and connections to occur, but these processes can still be potentiated by neutralization or deletion of the neurite growth inhibitors in the mature CNS. 
were absent (Liebscher et al. 2005). Most remarkably, pain thresholds were not different from the ones in control animals and spasticity decreased in anti-Nogo-A antibody-treated spinal cord-injured rats (Liebscher et al. 2005; Gonzenbach et al. 2010). Absence of malfunctions was also seen in experiments with spinal cord-injured macaques, whereas skilled hand and finger movements recovered almost completely following high cervical spinal hemisection lesions and a 1-mo intrathecal anti-NogoA antibody infusion (Freund et al. 2006, 2009). A phase 1 clinical trial with intrathecal application of a function-blocking anti-Nogo-A antibody over $30 \mathrm{~d}$ in acutely and severely spinal cord-injured patients confirmed the absence of negative side effects of this treatment also in humans (Abel et al. 2011).

In stroke models, suppression of Nogo-A or NgR1 enhanced the compensatory sprouting of the spared, contralesional corticofugal system, which grew across the brain stem and spinal cord midline and reinnervated the denervated side. This process was associated with a very high degree of recovery of skilled movements, in particular, the forelimb (Cafferty et al. 2008; Tsai et al. 2011; Lindau et al. 2013). In experimental allergic encephalomyelitis, a well-studied rodent model for multiple sclerosis, Nogo-A $\mathrm{KO}$, antibodies against Nogo-A or NgR1 KO led to a milder disease course and higher functional recovery (Karnezis et al. 2004; Yang et al. 2010; Petratos et al. 2012).

Whether simultaneous deletion of several inhibitory factors and/or very massive stimulation of the intrinsic neuronal growth program (Liu et al. 2011) would yield more extensive regeneration and functional repair than what has been obtained up to now requires systematic additional studies. The danger exists, however, that guidance and target interaction mechanisms of the adult CNS, which are required to establish and control new circuits and keep the CNS wiring in a stable condition, could be overrun, and chaotic connections and malfunctions, for example, epilepsies, could result. A remarkable finding has also been that (conventional) KO mice for Nogo or its receptor NgR1 have repeatedly resulted in milder fiber regrowth effects than acute interventions with, for example, neutralizing antibodies or receptor-blocking peptides (Dimou et al. 2006; Cafferty et al. 2010; Lee et al. 2010; Schwab 2010). For a NogoA KO mouse, the up-regulation of several ephrins and semaphorins and their receptors has recently been shown (Kempf et al. 2013). This represents a striking example of functional compensation of the lack of a physiologically important molecule by the organism and underlines the role of myelin-associated neurite growth inhibitory factors for the homeostasis of the adult CNS.

\section{ASTROCYTES AND GLIAL PROGENITOR CELLS PLAY CRITICAL ROLES IN REGENERATION FAILURE}

The Glial Scar and PNN: ProteoglycanMediated Inhibition of Regeneration and Sprouting

A wide variety of injuries or diseases of the CNS, which are severe enough to cause a breach in the blood-brain barrier or overt bleeding, lead to secondary tissue damage, resulting in the encapsulation of the lesion by reactive astrocytes, which form the so-called glial "scar." The scar is an essential part of wound healing in the brain and spinal cord because it serves to physically and molecularly wall off zones of intense inflammation to provide a measure of protection for the remaining fragile tissue (Silver and Miller 2004). This portion of the review will describe current thinking about the biological consequences of glial scarring in the spinal cord, especially, as it affects wound repair and axon regeneration; however, it is likely that similar events occur throughout the CNS.

The astroglial component of the scar wall is formed by at least five critical processes. The first is the rapid (within days) migration of astrocytes from the lesion epicenter toward its outermost edges, actively driven away by as-yet-unknown factors produced by inflammatory cells (Fitch and Silver 1997). The second is proliferation of the thin layer of reactive astrocytes (gliosis), which comes to reside just at the lesion margin (reactive astrocytes further away do not mark- 
J. Silver et al.

edly increase their proliferation rates, nor do they migrate extensively) (Bush et al. 1999; Faulkner et al. 2004; Wanner et al. 2013). The third is the accumulation of intermediate filament proteins, predominantly glial fibrillary acidic protein (GFAP), vimentin, and nestin, leading to cellular hypertrophy of the astrogliotic layer, as well as nondividing reactive astrocytes further away (Pekny et al. 1999; Xu et al. 1999; Wilhelmsson et al. 2004; Bardehle et al. 2013). The fourth involves the restructuring of the gliotic layer into a mesh-like envelope, which changes from a radial, longitudinal orientation to an alignment largely perpendicular to the long axis of the cord and is, thus, highly obstructive to any potential regrowth of the major projection axon pathways (Bardehle et al. 2013; Wanner et al. 2013). In addition, there occurs the production of a variety of potently growth inhibitory extracellular matrix (ECM) molecules, among which are the lectican family of CSPGs (McKeon et al. 1991, 1995, 1999; Davies et al. 1999; Yamaguchi 2000; Busch and Silver 2007; Alilain et al. 2011; Brown et al. 2012; Kawano et al. 2012; Li et al. 2013; Takeuchi et al. 2013). Thus, the scar presents a physical and molecular constraint against the release of intralesional inflammatory agents, but also, unfortunately, to axon regeneration.

It is now known that this entire cascade of events is triggered, in part, by TGF- $\beta$ bound to fibrinogen, which pores in through the leaky or hemorrhagic blood-brain barrier and activates the SMAD2 signaling cascade. Blocking the TGF- $\beta$ receptor pathway abolishes the fibrinogen-induced effects on glial scar formation and, in particular, reduces proteoglycan deposition (Schachtrup et al. 2010). The early migratory response of astrocytes appears to be, at least in part, under the control of glycogen synthase kinase-3 (GSK-3) activity because acute treatment with a potent GSK-3 inhibitor accelerates migration, resulting in better sequestration of inflammatory cells and significantly enhanced functional improvement (Renault-Mihara et al. 2011). Also, the transcription factor SOX9 appears to be a critical component of the pathway that leads to inhibitory matrix deposition in the lesion because its conditional KO leads to reduced expression of various CSPGs and improved locomotor function (Mckillop et al. 2013). The architectural glial changes are under the control of STAT3. When this transcription activator is genetically deleted in astrocytes (or the proliferating/gliotic astrocytes are themselves deleted), the walling off phenomenon is severely perturbed and inflammatory infiltrates invade much larger regions of the cord, leading to rampant tissue destruction and further loss of function (Bush et al. 1999; Herrmann et al. 2008; Wanner et al. 2013). Another critical molecular determinant of astroglial scar building is injury-induced glial $\mathrm{Ca}^{2+}$ signaling, which regulates expression of the cell-to-cell adhesion molecule N-cadherin. This calcium-dependent tight adhesion-forming molecule likely plays an important role in strengthening the scar wall (Kanemaru et al. 2013). N-cadherin binds the fibroblast growth factor receptor (FGFR) and activates a FGFR-dependent signaling cascade, which, in turn, can enhance GFAP expression and is known to play a critical role in controlling the polarity of astrocytes (Goldshmit et al. 2012; Lee et al. 2013; Macaya et al. 2013). In its absence, $\mathrm{N}$-cadherin $\mathrm{KO}$ mice display abnormal scar formation, leading to increased neuronal death (Kanemaru et al. 2013). Thus, the astrocytic response to injury is an essential component of damage control in the CNS, and the large number of molecular determinants involved with scar formation could be potential therapeutic targets.

There are also reactive changes in astrocytes much further away from the lesion, which eventually fill in the space vacated by dying oligodendrocytes and axons undergoing Wallerian degeneration (WD), but the structural changes here take a much longer time to manifest (Silver and Miller 2004; Wanner et al. 2013). Over extended periods of time, astroglial hypertrophy at the lesion edge, and in the tract beyond, leads to very dense aggregates of cells that, at the lesion and distally, especially near the pial surface, become obstructive to axonal regeneration (Silver and Miller 2004). Interestingly, denervated target regions, which are distant from the lesion, also undergo reactive glial changes, again associated with the production of sulfated proteo- 
glycans that are largely contained within the PNN (Massey et al. 2006; Alilain et al. 2011; Andrews et al. 2012; Hansen et al. 2013). The molecular triggers, which instigate up-regulation of these net-associated proteoglycans far from lesions, are largely unknown, but also appear to be regulated, in part, by the SOX9 transcription factor pathway (Mckillop et al. 2013) as well as neuronal activity (Wang and Fawcett 2012). CSPG up-regulation within the PNN is extremely important because it serves to limit potential functional plasticity, which could occur via compensatory sprouting from surviving inputs (Hockfield et al. 1990; Yamada et al. 1997; Berardi et al. 2004; Massey et al. 2006; Pizzorusso et al. 2006; Gogolla et al. 2009; García-Alías et al. 2011; Kwok et al. 2011; Wang and Fawcett 2012; de Vivo et al. 2013; Xue et al. 2014).

Oligodendrocyte Progenitor Cells and the Neuroglial 2 Proteoglycan: The Role of the Lesion Core in Regeneration Failure

Although the astroglial component of scar formation and its purported role in regeneration failure has been suggested for more than a century (Ramón y Cajal 1928; Windle and Chambers 1950) and has been clearly revealed by the use of microtransplantation experiments ( $\mathrm{Da}$ vies et al. 1997, 1999), the astroglial capsule is not solely responsible for axonal regeneration failure. When one examines, precisely, the interactions that occur between dystrophic axon tips and the cells that they closely associate with over time, it was surprising to learn that, for the most part, severed axons do not interact directly with reactive astrocytes, but rather with a population of neuroglial-2-proteoglycan (NG2)-producing oligodendrocyte precursor cells (OPCs) within the core of the lesion (Busch et al. 2010; Filous et al. 2010). It had long been thought that after SCI, severed axons would retract back to sustaining collateral (Ramón y Cajal 1928), and, thus, the free segment of remaining axon within the white matter would eventually be eliminated. However, with the advent of modern labeling techniques, we now know that, following the phase of axonal retraction (which is largely the result of an aggressive attack on the dystrophic axon tip by inflammatory blood-derived macrophages) (Horn et al. 2008; Busch et al. 2009; Evans et al. 2014), axotomized neurons often survive (Kwon et al. 2002; Nielson et al. 2010). Eventually, the cut axon stops retracting and its dystrophic tip can come to rest for many years (even decades) (Ruschel et al. 2013) within the penumbra of the lesion ( $\mathrm{Li}$ and Raisman 1995; Guest et al. 2005; Kadoya et al. 2009). What maintains the dystrophic end of the axon chronically within the hostile environment of the glial scar? Are the mechanisms involved with longterm maintenance of the severed axon critical to regeneration failure? Although SCI results in astroglial emigration away from the lesion, inside the core of the lesion, during the first several weeks postinjury, there is a robust recruitment and proliferation of a wide variety of cell types, which all become surrounded by astroglial scar. In addition to the vast array of activated blood-derived macrophages and other inflammatory cells, which begin to invade the lesion core within the first day (Popovich and Longbrake 2008; Kigerl et al. 2009; Evans et al. 2014), the normally rarely dividing ependymal cells around the central canal become activated and rapidly proliferate (Meletis et al. 2008). Within the first week, they also move into the core of the lesion and, as they do so, they downregulate their ependymal markers and begin to display reactive astroglial phenotypes, thus, contributing to the glial scar (Johansson et al. 1999). Additionally, after penetrating injuries that open the dura mater, but also, importantly, after contusive or ischemic injuries that leave the meninges largely intact, fibroblast-like stromal cells, which are derived from the meninges or pericytes or pericyte-like cells located around the perimeter of blood vessels, divide vigorously and slough off from the meninges or vasculature to help populate the lesion epicenter (Decimo et al. 2011; Göritz et al. 2011; Fernandez-Klett et al. 2013; Sabelström et al. 2013; Soderblom et al. 2013). These cells interact with the astroglial component of the scar and form a fibrotic-like layer internal to the astroglial capsule. Via their interactions with astrocytes and the collagenous/proteoglycan-rich matrices that are pro- 
J. Silver et al.

duced, they also play a role in helping to seal the lesion, but also may play a role in blocking regeneration (Davies et al. 1999; Stichel et al. 1999; Kawano et al. 2012; Sabelström et al. 2013; Soderblom et al. 2013). Finally, there occurs a robust proliferation of OPCs, which produce the purportedly potently inhibitory NG2 CSPG, as well as a cocktail of growth-promoting ECM molecules, including laminin and fibronectin (Zai and Wrathall 2005; Lytle et al. 2006; Busch et al. 2010). Thus, the early lesion core becomes a rich oasis of cells with a mixture of growthinhibiting and -promoting properties.

The role of NG2 $2^{+}$cells, both in the normal $\mathrm{CNS}$ and after injury, remains controversial. NG2 is a member of the CSPG family of ECM molecules that is thought to contribute to regeneration failure. Because NG2 is one of the most dramatically up-regulated CSPG after CNS injury (Levine 1994), it has been suggested that $\mathrm{NG}^{2}$ cells are "the" major regeneration-blocking cell type (Dou and Levine 1994; Fidler et al. 1999; Chen et al. 2002; Tan et al. 2006). In contrast, several studies suggest that $\mathrm{NG}^{+}$cells may not be repulsive at all. Indeed, the dystrophic tips of severed axons, which remain within the lesion penumbra for extended periods, reside closely among $\mathrm{NG}^{+}$glia (Zhang et al. 2001; McTigue et al. 2006; Busch et al. 2010) and $\mathrm{NG}^{+}$cells seem to facilitate growth of developing axons (Yang et al. 2006). Our laboratory suggested that the population of stem-like, NG2-producing cells in the lesion core may contribute to regeneration failure by acting as a kind of "safe haven" for dystrophic axons, stabilizing them as they are forced to retract backward into the caudal end of the lesion by activated macrophages (Busch et al. 2010). Indeed, severed axons in the lesion appear to be "addicted" to the surface of these cells and refuse to leave. However, the mechanisms that govern this tight cellcell interaction and, in particular, whether the NG2 CSPG is involved in this close association, remained important and unresolved questions.

Recently, we sought a better understanding of the interaction between severed sensory axons and adult cord-derived NG2 glia after a dorsal column injury (Filous et al. 2012). In our studies, we observed a novel mechanism of regener- ation failure. When combined with growthpromoting ECM molecules in critical ratios, purified NG2 and other CSPGs initially constrain axons to their territory via a GAG/LAR family CSPG receptor-mediated interactive mechanism (Shen et al. 2009; Filous et al. 2010; Fisher et al. 2011; Lang et al. 2012, 2013). NG2 glia also constrain early axonal outgrowth but, in addition, can lead to longer lasting entrapment of the neuron onto the glial cell surface through an unusual neuroglia synaptoid-mediated stabilization, both in vitro and in vivo. Given that neurons form synapses with $\mathrm{NG} 2^{+}$OPCs under physiological conditions throughout the CNS (Bergles et al. 2000; Chittajallu et al. 2004; Lin et al. 2005), it is possible that such synaptic-like interactions within the damaged white matter allow for long-lasting associations between the dystrophic tips of sensory neurons and $\mathrm{NG}^{+}$ cells. Although these stabilizations, initially, may be beneficial to prevent further dieback (Filous et al. 2010), they may also place further limitations on the forward movements of the struggling axon tip. The idea that synaptic-like connections form between regenerating axons and reactive glia, and may serve to curtail axonal regrowth after injury, had been suggested many years ago (Carlstedt 1985), although the importance of this phenomenon in regeneration failure had largely been abandoned. After a dorsal root crush, even following a peripheral conditioning lesion, injured sensory axons can regenerate rapidly within the proximal root until they reach the dorsal root entry zone (DREZ), a transitional region between the peripheral nervous system (PNS) and the CNS, where they abruptly halt their forward progress and remain (Carlstedt 1985; Liuzzi and Lasek 1987; Di Maio et al. 2011). Early studies suggested that, as peripheral axons regenerate toward the CNS, they contact reactive astrocytes, which initiate the early stages of so-called synaptoid formations in close association with the astrocyte surface. Interestingly, our current studies suggest that, in addition to their wall-building job, reactive astrocytes may also play an indirect role in signaling for sensory axons to begin synapse formation mediated, at least in part, via thrombospondins, which are important in regulating 
neuron-to-neuron synaptogenesis (Christopherson et al. 2005). However, our data show clearly that dystrophic axons after DCC are actually synapsing on the $\mathrm{NG}^{+}$cell, rather than astrocytes, and this relationship is also likely to occur at the DREZ. It is also possible that reactive astrocytes can directly induce proliferation of OPCs by releasing the mitogen, Sonic hedgehog $(\mathrm{SHH})$ into the injury environment (Amankulor et al. 2009). Activation of the SHHGli-signaling axis within the OPC population results in its dramatic expansion and the potential amplification of OPC-mediated effects on severed axons. It is also probable that inflammatory cells play a role in accelerating OPC mitosis as well (Miron et al. 2013).

This close interaction between $\mathrm{NG}^{+}$cells and injured neurons after SCI provides a new way of thinking about how CSPGs and the core of the scar "inhibit" axonal migration and helps explain how dystrophic axon tips persist within the scar-encased, hostile lesion environment. Thus, we hypothesize that in vivo within the scar core, CSPGs do not cause axon tips to cease growing because of a lack of adhesion, but rather because they create dystrophy and increasing entrapment of the growth cone via abnormally strong bonds with the substrate. Thus, the scar, with its two distinct regions (the core and the wall), can inflict a measure of inhibition that thwarts the advancement of the regenerating neuron (see Fig. 1).

\section{Plasticity of Reactive Astrocytes?}

The final question that I would like to speculate on is whether reactive astrocytes in the scar wall are permanently refractory to axonal regeneration or whether they can become plastic and promote or, at least, allow axonal growth (as they do during development) (Silver et al. 1982, 1993; Silver and Ogawa 1983). Emerging data suggests that they can be plastic and regeneration failure through the scar is the result of an imbalance between a lack of intrinsic growth machinery in the neuron (Ylera et al. 2009) and extrinsic forces (some of which are discussed above) that limit growth. Astrocytes that contribute to the scar and are derived from the ependymal tube appear to be slightly more "immature" than astrocytes derived from self-duplication because they express less GFAP relative to vimentin (Fig. 2) (Meletis et al. 2008). It would be very interesting if the well-known regeneration-enhancing functions of ependymoglial cells that are present in robustly regenerating cold-blooded species (Singer et al. 1979) are retained, at least to some extent, in the ependymal subpopulation of reactive astrocytes in scar tissue of mammals (Silver and Steindler 2009). Potential functional differences between astrocyte populations in the scar may be appearing in the rather dramatic ability of neurons to regenerate their severed axons right across and beyond carefully crafted lesions within the rodent spinal cord or optic nerve following PTEN/SOCS3 deletion (Park et al. 2010; Sun et al. 2011). Indeed, the impressive regeneration, albeit across relatively narrow lesions, when the protein products of these growth or cytokine regulatory genes are diminished or genetically deleted, is strictly confined to and dependent on astroglial bridges, which form spontaneously across the lesion core (Filous et al. 2010; Zukor et al. 2013). The appreciation of whether separate reactive astroglial subpopulations exert these guidance functions or possibly even if gliotic astrocytes in the scar wall can be plastic and made growth permissive or even promoting in response to the presence of a robustly growing axon, could be very important and therapeutically provocative (Ahmed et al. 2005). It would suggest that we consider strategies tailored toward amplifying or attenuating particular, functionally distinct astrocyte subpopulations or to further enhance the plasticity of gliotic astrocytes to help maximize functional recovery.

\section{MICROGLIA AND MACROPHAGES}

\section{Origin of Macrophages in Injured CNS}

In parallel with the injury-induced changes described above for oligodendrocytes and astrocytes, a robust and long-lasting inflammatory response is initiated, which is dominated by macrophages. These cells are mostly derived from two sources: (1) resident microglia, and 
J. Silver et al.
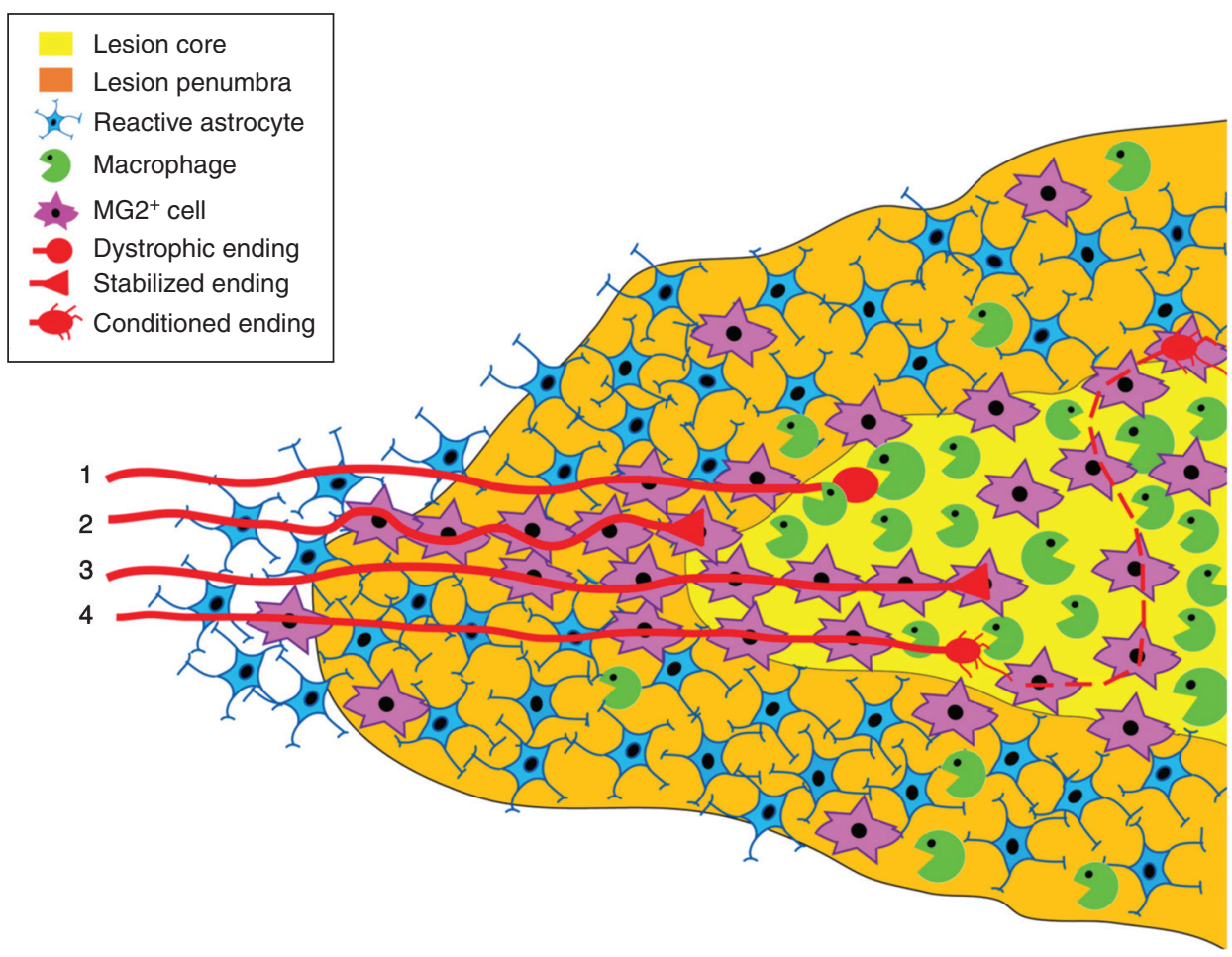

Figure 2. Schematic representation of the proximal end of a dorsal column crush lesion $7 \mathrm{~d}$ after injury. GFAP ${ }^{+}$ astrocytes (blue) have pulled away from the lesion core, which is now populated by $\mathrm{NG}^{+}$cells (purple) and phagocytic $\mathrm{ED}^{+}$macrophages (green). The fibroblastic and ependymal cell types are not displayed, but are also plentiful in the lesion core. Dorsal root ganglion neurons (red) attempt to regenerate into the lesion core. (1) Typical axon with a dystrophic growth cone that has become susceptible to macrophage attack. (2) Typical axon that has undergone macrophage-mediated retraction back to $\mathrm{NG}^{+}$cells and stabilized. (3) Atypical axon that has stabilized further distally within the lesion core on a contiguous bridge of $\mathrm{NG}^{+}$cells. (4) Growth cone of a neuron that has been stimulated or conditioned and able to overcome macrophage-induced axonal dieback and extend into the lesion core on $\mathrm{NG}_{2}{ }^{+}$cells. (From Busch et al. 2010; reprinted, with express permission, from the Journal of Neuroscience and the investigators of this review.)

(2) blood monocytes, that is, macrophage precursors that emigrate from bone marrow or the spleen (Popovich et al. 1999; Popovich and Hickey 2001; Longbrake et al. 2007; Swirski et al. 2009; Blomster et al. 2013). Microglia originate from precursor cells in the yolk sac and become homogeneously distributed throughout the CNS during early embryogenesis (Ginhoux et al. 2010). Like astrocytes, microglia respond rapidly to injury, extending cellular processes or migrating toward the lesion site where they participate in scar formation (Davalos et al. 2005; Dibaj et al. 2010). Surely, this early and rapid response serves a protective role, as there is no obvious evolutionary advan- tage for blanketing the CNS with cells that, when provoked, will mobilize and destroy delicate nervous tissue. Indeed, blocking or preventing microglial activation, via either pharmacologic or genetic means, exacerbates lesion pathology and impairs recovery of function ( $\mathrm{La}-$ lancette-Hébert et al. 2007; Hines et al. 2009).

After a delay of $\sim 2 \mathrm{~d}$ postinjury, monocytes bind to endothelial adhesion molecules and then migrate into the lesioned CNS, down chemotactic gradients established by astrocytes (Pineau et al. 2010). Shortly thereafter, monocytes differentiate into tissue macrophages. Because microglia and MDMs are both of myeloid lineage, lineage-specific markers cannot be used 
to distinguish between these major CNS macrophage subsets. Equally ambiguous is the effect that CNS macrophages have on neurons and axons that survive after CNS injury.

Seemingly conflicting data implicate macrophages, regardless of their source, as effectors of both tissue repair and secondary tissue damage. Although Ramón y Cajal is often recognized as the "father of neuroscience," he also provided some of the earliest descriptions of neuroimmune interactions in the injured CNS. Specifically, he noted that macrophages accumulated and persisted at sites of injury and concluded that their primary role was as scavenger cells (Ramón y Cajal 1991):

This leukocytic invasion of the dead neuron is not surprising. It is a general law that any mortified portion, no matter what is its character, becomes a pasture-ground for phagocytes. We believe that the protagonists of all acts of neuronophagy are nothing else than the granular corpuscles which accumulate so prodigiously in the necrotic focus of the centres and in the peripheral stumps of degenerated nerves.

Because he did not have the benefit of modernday techniques (e.g., radiation bone-marrow chimeras, transgenic mice, etc.), Ramón y Cajal and his contemporaries were unable to unequivocally determine the origin of CNS macrophages. Regardless, he accurately predicted that most phagocytes present in lesioned CNS tissue were derived from blood, that is, monocytes:

... we believe also that the phagocytes-our traumatocytes-which have penetrated into the neuronal cadaver positively represent large leucocytes with a lobulated nucleus, which have come from the host's blood.

We now know that his predictions were correct and the biased accumulation of MDMs at the lesion center may have significant implications for the growth or retraction ("dieback") of injured axons (see below).

\section{Macrophage Functions in Injured CNS}

Some years after Ramón y Cajal's seminal observations (circa 1950), additional insight into CNS macrophage function was gleaned from a serendipitous discovery. Although studying neural mechanisms of thermal regulation in dogs with SCI, Windle, Clemente, and colleagues discovered that deliberate systemic injection of pyrogens had the unintended benefit of enhancing neurologic recovery (Windle and Chambers 1950; Clemente and Windle 1954). Postmortem analysis of dogs injected with crude pyrogens revealed markedly increased numbers of intraspinal macrophages and reduced intralesional scarring as compared with injured spinal cords of untreated dogs (Clemente and Windle 1954). Almost 30 years later, Guth and colleagues extended Windle's observations showing that systemic injections of purified endotoxin (i.e., lipopolysaccharide [LPS]) into spinal-injured rats enhanced intraspinal leukocytosis beyond that normally seen after SCI (Guth et al. 1994a). This enhanced inflammatory reaction was accompanied by more robust axon growth and quantitatively superior improvements in hindlimb locomotor function. Guth later found that the salutary effects of LPS could be further improved by simultaneously treating animals with anti-inflammatory agents, including indomethacin or steroids (Guth et al. 1994b). This combination approach, although seemingly counterintuitive, was based on keen insight regarding the divergent functions of activated CNS macrophages. Guth realized that, during maturation, macrophages become "primed" or partially activated by cytokines (and other factors) present in the injury milieu; however, to attain a greater level of functional competency, including the ability to promote axon growth or neuroprotection, macrophages likely require a second distinct signal, in this case, LPS. He also recognized that once activated, these same cells release hydrolyzing enzymes, oxidative metabolites, and arachadonic acid metabolites (e.g., prostaglandins), which can damage neurons and glia. Indomethacin and steroids were used to inhibit these destructive secretory components of activated macrophages.

Over the next $10-15 \mathrm{yr}$, data from several laboratories using rabbit, guinea pig, and rat models of SCI showed that, in the absence of a secondary stimulus, the injurious effects of in- 
J. Silver et al.

traspinal macrophages predominate. Regardless of species, injury type (e.g., compression, contusion), or injury severity, selective inhibition or depletion of macrophages during the first 1-2 wk postinjury consistently reduces secondary or bystander tissue injury, leading to improved recovery of sensory, motor, or autonomic functions (Giulian and Robertson 1990; Blight 1994; Popovich et al. 1999; Gris 2004).

Emerging data now indicate that in response to different combinations of factors, which are normally found in the extracellular milieu of the injured nervous system, macrophages differentiate into functionally distinct cell subsets that differentially affect neuron survival and axon growth (Stout et al. 2005; Kigerl et al. 2009). For example, cytokines, cell fragments, and nucleic acids promote differentiation of macrophages into "classically" (M1) or "alternatively" activated (M2) cells. The canonical in vitro model for promoting inflammatory M1 macrophage differentiation is exposure of native (unstimulated) myeloid cells to LPS and inflammatory cytokines, including interferon (IFN)- $\gamma$ or tumor necrosis factor (TNF)- $\alpha$. Alternatively, to promote M2 differentiation, immature myeloid cells are stimulated with interleukin (IL)-4 or -13 (Gordon and Taylor 2005). After CNS injury, signaling pathways that polarize macrophages toward an M1 phenotype predominate (Kigerl et al. 2009; David and Kroner 2011). M1 macrophages can be neurotoxic and cause axon dieback (Horn et al. 2008; Kigerl et al. 2009). Thus, the neuroprotective effects of acute macrophage inhibition or depletion in SCI models might be explained by reducing the burden of M1 macrophages at the injury site. Surprisingly, these same cells also can enhance neurite outgrowth.

In vivo injections of inflammatory stimuli (e.g., LPS, zymosan), which are needed to promote an M1 macrophage phenotype in vitro, enhance regeneration of injured peripheral and central axons (Yin et al. 2003; Steinmetz et al. 2005; Boivin et al. 2007; Gensel et al. 2009). In injured brain, spinal cord, and optic nerve, macrophage clusters are often associated with sprouting of injured axons (Fig. 3). This endogenous repair phenomenon is mediated by macrophages via the release of neurotrophins and growth factors or, indirectly, by activating glia within the scar, which subsequently produces a trophic gradient. BDNF, CNTF, and glial cell line-derived neurotrophic factor (GDNF) have been implicated in this response (Batchelor et al. 2002; Yin et al. 2006; Muller et al. 2007; Gensel et al. 2009; Benowitz and Popovich 2011). The ability of transplanted microglia or macrophages to promote neurite outgrowth in different models of SCI might be explained by a similar mechanism (Prewitt et al. 1997; Rabchevsky and Streit 1997; Rapalino et al. 1998).

Compared with M1 macrophages, M2 macrophages may be less destructive and better able to repair the injured CNS. M2 macrophages promote more robust neurite outgrowth and recent data show that these cells release activin-A, which enhances oligodendrocyte progenitor cell differentiation and, subsequently, remyelination (Kigerl et al. 2009; Miron et al. 2013). Enhancing M2 microglia/macrophage differentiation in lesioned CNS tissues is associated with neuroprotection; however, limited data exist linking M2 macrophages with axon regeneration in vivo. Combining peripheral nerve grafts with acidic fibroblast growth factor in an injured spinal cord produces a cytokine milieu that favors M2 macrophage differentiation, polyamine synthesis with improved axon regeneration (Kuo et al. 2011). Similarly, infusion of IL-4 (M2 cytokine) into guidance channels placed into injured sciatic nerves induces an M2 macrophage response that stimulates Schwann cell migration with enhanced axon regeneration into the distal nerve stump (Mokarram et al. 2012).

\section{Manipulating Macrophages to Promote Axon Regeneration: Future Considerations}

ProCord was an experimental cell-based therapy that was developed to treat acute SCI in humans. Clinical trials were initiated by Proneuron Biotechnologies (New York, NY) based on data showing that autologous macrophages, when activated ex vivo, then injected into the injured spinal cord, promote axon regeneration and 
CNS Regenerative Failure

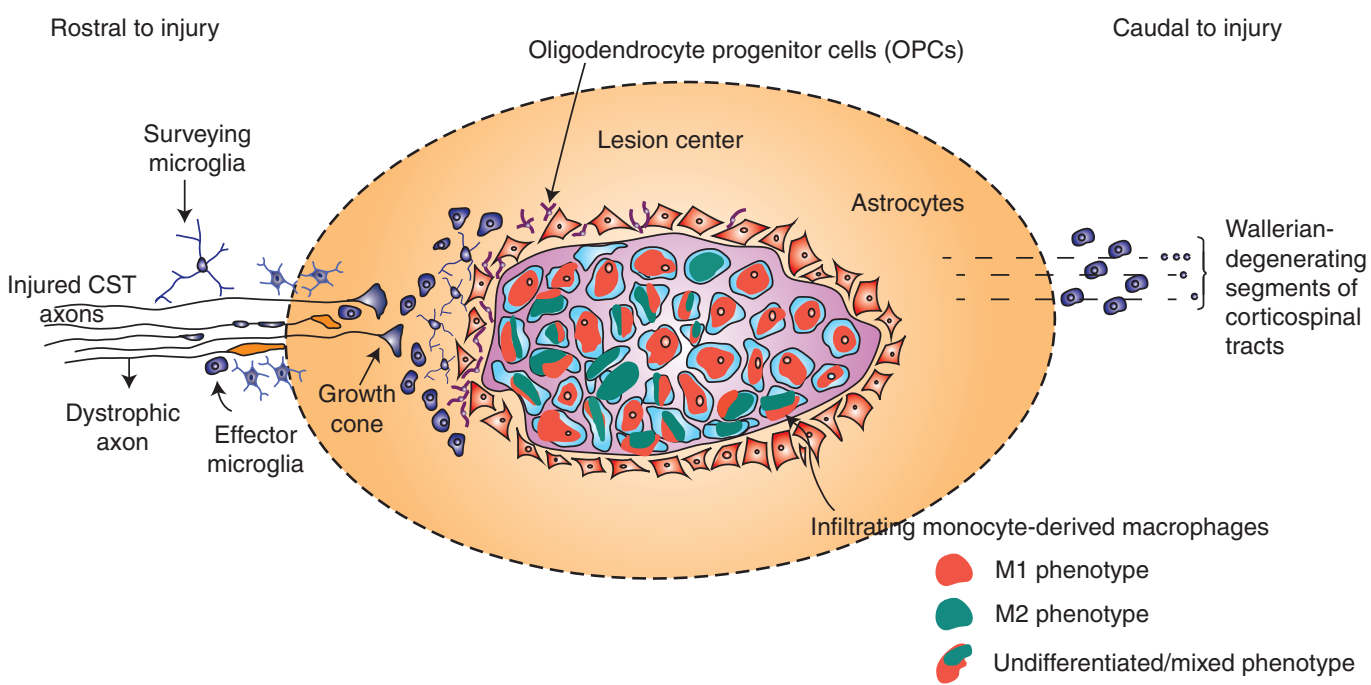

Figure 3. Schematic of microglia and MDM reactions elicited by SCI. After injury, the lesion center (also referred to as "epicenter" in contusion lesions) becomes filled with phagocytic macrophages derived from blood monocyte precursors. These cells become enlarged as they phagocytose lipid and cell debris. These and other stimuli in the lesion prime an M1 macrophage phenotype (red). Only a subset of macrophages become "alternatively" activated (i.e., M2 macrophages, green). Some cells remain undifferentiated or adopt a heterogeneous phenotype (orange/green mix). Macrophages in the lesion center are "walled off" by reactive astrocytes, which create a scar. OPCs interdigitate between scar-forming astrocytes and are drawn toward the lesion edge by undefined factors. Complete OPC differentiation into myelinating oligodendrocytes may require factors derived from (M2) microglia subsets, which often lie outside the lesion microenvironment (gradient fill). Microglia exist in intact spinal cord as sentinel cells, which continuously survey the microenvironment. After injury or in response to subtle changes in homeostasis, microglia become activated and transform morphologically and phenotypically into effector microglia. Depending on the composition of factors present in the microenvironment, microglia can become polarized to become M1 or M2 effector cells. Rostral to the site of injury, surveying and effector microglia colocalize with damaged axons, a subset of which are undergoing dieback, but also with a subset that are stabilized or attempting to grow. Caudal to the lesion, descending axons undergo Wallerian degeneration (WD). Various factors released during WD activate microglia (and macrophages). It is common to see effector microglia (and, presumably, a subset of MDMs) colocalized with WD axon segments. CST, corticospinal tract.

reduce tissue damage in two different rodent SCI models (Rapalino et al. 1998; Bomstein et al. 2003). An overview of the rationale and design for the phase I trial was reviewed previously ( $\mathrm{Ki}-$ gerl and Popovich 2006). Results of the phase 2 randomized controlled multicenter trial, involving 43 participants, showed a trend for better recovery in the control group relative to patients receiving macrophage transplants, but without group differences in the number of adverse events (Lammertse et al. 2012). Although efficacy was not established, future cell-based clinical trials for SCI (and other diseases) will benefit from the ProCord experience, because this trial identified and overcame numerous logistical and technical constraints associated with enrolling, preparing, and injecting into the spinal cord within $14 \mathrm{~d}$ of injury, an autologous cellular therapy (Jones et al. 2010).

Autologous macrophage transplantation remains a promising therapeutic approach; however, new preclinical data indicate that the phenotype of macrophages generated ex vivo may not persist after injection into lesioned CNS. When M2 polarized macrophages are transplanted into lesioned spinal cord, they differentiate into M1 macrophages. Conversely, M2 macrophages maintain their phenotype when transplanted into intact spinal cord (Kigerl et al. 2009). Accordingly, future transplantation 
J. Silver et al.

protocols, whether macrophages or other cell types, will need to incorporate measures that modify the lesion microenvironment. Generic immune suppressive drugs (e.g., steroids) are not practical in this context because these drugs will affect injurious and reparative macrophage subsets. Generic macrophage inhibition or depletion strategies, including intravenous injections of anti-integrin antibodies or liposomeencapsulated bisphosphonates, could be useful, especially in the acute postinjury period or if used together with neuroprotective drugs (Popovich et al. 1999; Gris 2004; Iannotti et al. 2011; Lee et al. 2011). Neuropeptides (e.g., substance P), antibodies that block cytokine signaling or stem cells, also could be used as each is able to modulate the injury milieu, creating an environment that favors polarization of endogenous macrophages toward an M2 phenotype (Busch et al. 2011; Cusimano et al. 2012; Guerrero et al. 2012).

In addition to macrophage transplantation, targeted or "precision" immunotherapies, which inhibit or stimulate one or more phenotypically distinct macrophage subsets, is an ideal approach. Along with the M1/M2 CNS macrophage subsets described above, new reagents and genetic tools have revealed the presence of other distinct intraspinal macrophage subsets (Thawer et al. 2013). For example, variations in the relative expression of the chemokine receptor CX3CR1 or maturation markers (e.g., Ly6) define functionally distinct CNS macrophages (Shechter et al. 2009; Donnelly et al. 2011; Saiwai et al. 2013). Antibodies and small molecule inhibitors can or have been designed to target these macrophages, but whether such manipulations will affect axon regeneration requires additional research. Ideally, future studies will incorporate acute and chronic CNS lesion models. Although macrophages persist indefinitely in CNS lesions, their role in the chronic injury milieu and nearby spared tissue is unknown.

The possibility that microglia and MDMs will have distinct effects on cell repair and axon regeneration after CNS injury is likely and should also be considered when designing or interpreting preclinical studies (Popovich and Longbrake 2008; London et al. 2013). Microglia and MDMs develop by discrete transcriptional control mechanisms from unique precursor cells (Prinz et al. 2011; Schulz et al. 2012). After injury, the discrete spatial distribution of different macrophage subsets produces heterogeneous microenvironments that can differentially affect injured axons, nascent axonal growth cones, and surrounding glia. Recent data show that signals emanating from aged brain trigger a neuroprotective transcriptomic signature in microglia (Hickman et al. 2013). Whether similar neuroregenerative or neurotoxic "sensomes" exist in microglia or MDMs, respectively, is unknown, but such profiles seem likely, especially because the ratio of microglia to MDMs increases in regions remote from the injury site, along with clear evidence of anatomical and functional plasticity or endogenous CNS repair (Zhang and Guth 1997; Popovich and Hickey 2001; Zhou et al. 2003; McTigue et al. 2006; Detloff et al. 2008; Busch et al. 2010; Hansen et al. 2013).

Conversely, physical contact between axons and macrophages within the lesion core (high ratio of MDMs to microglia) causes axons to retract or "dieback" from the injury site. Both soluble factors and cell surface proteins are culpable in this degenerative response (Horn et al. 2008; Busch et al. 2011). Macrophages express numerous membrane-bound proteins, including receptors for ephrins, siglecs (sialoadhesins), and integrins (Crocker et al. 1994; Sobel et al. 1995; Tang et al. 1997; Liu et al. 2006). Axon growth and guidance may be positively or negatively affected when these proteins are bound by corresponding ligands found on axons. Given the discrete spatiotemporal dynamics of macrophages and microglia, when, where, and how much injured axons are exposed to these cells will undoubtedly affect their ability to regenerate.

Although there is a growing appreciation that macrophages are important contributors to CNS regeneration failure, we have only a rudimentary understanding of how or whether these cells influence axon regeneration. Achieving a greater understanding of CNS macrophages should improve the safety and success of 
future clinical trials designed to promote regeneration or repair of the injured CNS.

\section{CONCLUSION}

Over the past several decades, there has been steady progress in understanding basic molecular mechanisms that are responsible for the poor regenerative potential of injured central nervous system axons. Indeed, there are limitations within the neuron, that is, molecular switches that impede intrinsic regeneration machinery, and there are various glial cells that create lesion barricades or "extrinsic" inhibitory cues, which curtail the relatively limited regenerative potential of injured CNS axons. In this review, we have focused on each of the major glial cell types that serve as the primary extrinsic regulators of axon regeneration with an emphasis on the injured spinal cord. We have described how the severed axon tip, struggling to advance a new growth cone, is collapsed by myelin-derived growth-inhibitory factors, made dystrophic by proteoglycans, and further attacked by the destructive actions of M1 macrophages, whose job, early on, is to phagocytose the noxious debris. The unfortunate neuron, whose axon was once enveloped by supportive oligodendrocytes and astrocytes, is left to fend for itself during the attack; oligodendrocytes die and reactive astrocytes abandon the core of the lesion as they attempt to protect and mechanically stabilize the remaining fragile tissue from an expanding inflammatory reaction, creating yet another obstacle to regeneration. But, there is some relief, even within the eye of the storm. Once neurotoxic macrophages convert into a more reparative M2 state, and various stemlike cells, including oligodendrocyte progenitors, begin to thrive within the lesion core, the retracting axon can find a safe haven and even form synaptic-like connections on the primitive glia where, unfortunately, they remain locked in place for decades. As we have acquired a more complete appreciation of the molecular mechanisms that control the untoward effects of glia, new approaches are being developed that can readily prevent axons from dying backward and also may allow them to robustly sprout or sometimes regenerate beyond the scar toward new functional synaptic targets. A major goal for the future will be to combine the most successful glia-targeted strategies with others that drive the neuron's intrinsic growth capacity to maximize the regenerative potential that we now know exists within the damaged adult CNS.

\section{REFERENCES}

Abel R, Baron HC, Casha S, Harms J, Hurlbert J, Kucher K, Maier D, Thietje R, Weidner N, Curt A. 2011. Therapeutic anti-Nogo-A antibodies in acute spinal cord injury: Safety and pharmacokinetic data from an ongoing firstin-human trial. ISCOS Meeting 2011, Washington, DC.

Aguayo AJ, Rasminsky M, Bray GM, Carbonetto S, McKerracher L, Villegas-Prez M, Vidal-Sanz M, Carter DA. 1991. Degenerative and regenerative responses of injured neurons in the central nervous system of adult mammals. Phil Trans R Soc B 331: 337-343.

Ahmed Z, Dent RG, Leadbeater WE, Smith C, Berry M, Logan A. 2005. Matrix metalloproteases: Degradation of the inhibitory environment of the transected optic nerve and the scar by regenerating axons. Mol Cell Neurosci 28: $64-78$.

Akbik, Feras V, Sarah M, Bhagat, Pujan R, Patel, William BJ, Cafferty, Stephen M, Strittmatter. 2013. Anatomical plasticity of adult brain is titrated by Nogo receptor 1 . Neuron 77: 859-866.

Alilain WA, Horn KP, Hu H, Dick TE, Silver J. 2011. Functional regeneration of respiratory pathways after spinal cord injury. Nature 475: 196-200.

Amankulor NM, Hambardzumyan D, Pyonteck SM, Becher OJ, Joyce JA, Holland EC. 2009. Sonic hedgehog pathway activation is induced by acute brain injury and regulated by injury-related inflammation. J Neurosci 29: 10299_ 10308.

Andrews EM, Richards RJ, Yin FQ, Viapiano MS, Jakeman LB. 2012. Alterations in chondroitin sulfate proteoglycan expression occur both at and far from the site of spinal contusion injury. Exp Neurol 235: 174-187.

Bardehle S, Kruger M, Buggenthin F, Schwausch J, Ninkovic J, Clevers H, Snippert HJ, Theis FJ, Meyer-Luehmann M, Bechmann I, et al. 2013. Live imaging of astrocyte responses to acute injury reveals selective juxtavascular preoliferation. Nat Neurosci 16: 580-586.

Batchelor PE, Porritt MJ, Martinello P, Parish CL, Liberatore GT, Donnan GA, Howells DW. 2002. Macrophages and microglia produce local trophic gradients that stimulate axonal sprouting toward but not beyond the wound edge. Mol Cell Neurosci 21: 436-453.

Berardi N, Pizzorusso T, Maffei L. 2004. Extracelluar matrix and visual cortical plasticity: Freeing the synapse. Neuron 44: 905-908.

Bergles DE, Roberts JD, Somogyi P, Jahr CE. 2000. Glutamatergic synapses on oligodendrocyte precursor cells in the hippocampus. Nature 405: 187-191.

Benowitz LI, Popovich PG. 2011. Inflammation and axon regeneration. Curr Opin Neurol 24: 577-583. 
J. Silver et al.

Blight AR. 1994. Effects of silica on the outcome from experimental spinal cord injury: Implication of macrophages in secondary tissue damage. Neuroscience 60: $263-273$.

Blomster LV, Brennan FH, Lao HW, Harle DW, Harvey AR, Ruitenberg MJ. 2013. Mobilisation of the splenic monocyte reservoir and peripheral $\mathrm{CX}_{3} \mathrm{CR} 1$ deficiency adversely affects recovery from spinal cord injury. Exp Neurol 247: 226-240

Boivin A, Pineau I, Barrette B, Filali M, Vallières N, Rivest S, Lacroix S. 2007. Toll-like receptor signaling is critical for Wallerian degeneration and functional recovery after peripheral nerve injury. J Neurosci 27: 12565-12576.

Bomstein Y, Marder JB, Vitner K, Smirnov I, Lisaey G, Butovsky O, Fulga V, Yoles E. 2003. Features of skin-coincubated macrophages that promote recovery from spinal cord injury. J Neuroimmunol 142: 10-16.

Brown JM, Xia J, Zhuang B, Cho K-S, Rogers CJ, Gama CI, Rawat M, Tully SE, Uetani N, Mason DE, et al. 2012. A sulfated carbohydrate epitope inhibits axon regeneration after injury. Proc Natl Acad Sci 109: 4768-4773.

Busch SA, Silver J. 2007. The role of extracellular matrix in CNS regeneration. Curr Opin Neurobiol 17: 120-127.

Busch SA, Horn KP, Silver DJ, Silver J. 2009. Overcoming macrophage mediated axonal dieback following CNS injury. J Neurosci 29: 9967-9976.

Busch SA, Horn KP, Causcut FX, Hawthorne AL, Bai L Miller RH, Silver J. 2010. Adult NG2 ${ }^{+}$progenitor cells are permissive to axon growth and stabilize sensory axons during macrophage-induced axonal dieback after spinal cord injury. J Neurosci 30: 255-265.

Busch SA, Hamilton JA, Horn KP, Cuascut FX, Cutrone R, Lehman N, Deans RJ, Ting AE, Mays RW, Silver J. 2011. Multipotent adult progenitor cells prevent macrophagemediated axonal dieback and promote regrowth after spinal cord injury. J Neurosci 31: 944-953.

Bush TG, Puvanachandra N, Horner CH, Polito A, Ostenfeld T, Svendsen CN, Mucke L, Johnson MH, Sofroniew MV. 1999. Leukocyte infiltration, neuronal degeneration and neurite outgrowth after ablation of scarforming, reactive astrocytes in adult transgenic mice. Neuron $\mathbf{2 3}$ 297-308.

Cafferty WB, McGee AW, Strittmatter SM. 2008. Axonal growth therapeutics: Regeneration or sprouting or plasticity? Trends Neurosci 31: 215-220.

Cafferty WB, Duffy P, Huebner E, Strittmatter SM. 2010 MAG and OMgp synergize with Nogo-A to restrict axonal growth and neurological recovery after spinal cord trauma. J Neurosci 30: 6825-6837.

Carbonetto S, Evans D, Cochard P. 1987. Nerve fiber growth in culture on tissue substrata from central and peripheral nervous systems. J Neurosci 7: 610-620.

Carlstedt T. 1985. Regenerating axons form nerve terminals at astrocytes. Brain Res 347: 188-191.

Chen ZJ, Negra M, Levine A, Ughrin Y, Levine JM. 2002. Oligodendrocyte precursor cells: Reactive cells that inhibit axon growth and regeneration. J Neurocytol 31: 481495.

Chittajallu R, Aquirre A, Gallo V. 2004. NG2-positive cells in the mouse white matter and grey matter display distinct physiological properties. J Physiol 561: 109-122.
Christopherson KS, Ullian EM, Stokes CCA, Mullowney CE, Hell JW, Agah A, Lawler J, Mosher DF, Bornstein P, Barres BA. 2005. Thrombospondins are astrocyte-secreted proteins that promote CNS synaptogenesis. Cell 120: 421433.

Clemente CD, Windle WF. 1954. Regeneration of severed nerve fibers in the spinal cord of the adult cat. J Comp Neurol 101: 691-731.

Colello R, Schwab ME. 1994. A role for oligodendrocytes in the stabilization of optic axon numbers. J Neurosci 14: 6446-6452.

Cregg JM, DePaul MA, Filous AR, Lang BT, Tran A, Silver J. 2014. Functional regeneration beyond the glial scar. Exp Neurol 253: 197-207.

Crocker PR, Mucklow S, Bouckson V, McWilliam A, Willis AC, Gordon S, Milon G, Kelm S, Bradfield P. 1994. Sialoadhesin, a macrophage sialic acid binding receptor for haemopoietic cells with 17 immunoglobulin-like domains. EMBO J 13: 4490-4503.

Cusimano M, Biziato D, Brambilla E, Donega M, AlfaroCervello C, Snider S, Salani G, Pucci F, Comi G, GarciaVerdugo JM, et al. 2012. Transplanted neural stem/precursor cells instruct phagocytes and reduce secondary tissue damage in the injured spinal cord. Brain 135: 447-460.

Davalos D, Grutzendler J, Yang G, Kim JV, Zuo Y, Jung S, Littman DR, Dustin ML, Gan W-B. 2005. ATP mediates rapid microglial response to local brain injury in vivo. Nat Neurosci 8: 752-758.

David S, Kroner A. 2011. Repertoire of microglial and macrophage responses after spinal cord injury. Nat Rev Neurosci 12: 388-399.

Davies SJA, Fitch MT, Memberg SP, Hall AK, Raisman G, Silver J. 1997. Regeneration of adult axons in white matter tracts of the central nervous system. Nature 390: 680683.

Davies SJ, Goucher DR, Doller C, Silver J. 1999. Robust regeneration of adult sensory axons in degenerating white matter of the adult rat spinal cord. J Neurosci 19: 5810-5822.

Decimo I, Bifari F, Rodriguez FJ, Malpeli G, Dolci S, Lavarini V, Pretto S, Vasquez S, Sciancalepore M, Montalbano A, et al. 2011. Nestin- and doublecortin-positive cells reside in adult spinal cord meninges and participate in injuryinduced parenchymal reaction. Stem Cell 29: 2062-2076.

Detloff MR, Fisher LC, McGaughy V, Longbrake EE, Popovich PG, Basso DM. 2008. Remote activation of microglia and pro-inflammatory cytokines predict the onset and severity of below-level neuropathic pain after spinal cord injury in rats. Exp Neurol 212: 337-347.

de Vivo L, Landi S, Panniello M, Baroncelli L, Chierzi S, Mariotti L, Spolidoro M, Pizzorusso T, Maffei L, Ratto GM. 2013. Extracellular matrix inhibits structural and functional plasticity of dendritic spines in the adult visual cortex. Nat Commun 4: 1484.

Dibaj P, Nadrigny F, Steffens H, Scheller A, Hirrlinger J, Schomburg ED, Neusch C, Kirchhoff F. 2010. NO mediates microglial response to acute spinal cord injury under ATP control in vivo. Glia 58: 1133-1144.

Dickendesher TL, Baldwin KT, Mironova YA, Koriyama Y, Raiker SJ, Askew KL, Wood A, Geoffroy CG, Zheng B, Liepmann CD, et al. 2012. NgR1 and NgR3 are receptors 
for chondroitin sulfate proteoglycans. Nat Neurosci 15: 703-712.

di Maio A, Skuba A, Himes BT, Bhagat SL, Hyun JK, Tessler A, Bishop D, Son Y. 2011. In vivo imaging of the dorsal root regeneration: Rapid immobilization and presynaptic differentiation at the CNS/PNS border. J Neurosci 31: 4569-4582.

Dimou L, Schnell L, Montani L, Duncan C, Simonen M, Schneider R, Liebscher T, Gullo M, Schwab ME. 2006 Nogo-A-deficient mice reveal strain-dependent differences in axonal regeneration. J Neurosci 26: 5591-5603.

Donnelly DJ, Longbrake EE, Shawler TM, Kigerl KA, Lai W, Tovar CA, Ransohoff RM, Popovich PG. 2011. Deficient CX3CR1 signaling promotes recovery after mouse spinal cord injury by limiting the recruitment and activation of Ly6Clo/iNOS ${ }^{+}$macrophages. J Neurosci 31: 9910-9922.

Dou CL, Levine JM. 1994. Inhibition of neurite outgrowth by the NG2 chondroitin sulfate proteoglycan. J Neurosci 14: 7616-7628.

Evans TA, Barkauskas DS, Myers J, Hare EG, You J, Huang AY, Silver J. 2014. High-resolution intravital imaging reveals that secondary axonal dieback in traumatic spinal cord injury is facilitated by blood derived macrophages but not microglia. Exp Neurol 254: 109-120.

Faulkner JR, Herrmann JE, Woo MJ, Tansey KE, Doan NB, Sofroniew MV. 2004. Reactive astrocytes protect tissue and preserve function after spinal cord injury. J Neurosci 24: 2143-2155.

Fawcett JW, Rokos J, Bakst I. 1989. Oligodendrocytes repel axons and cause axonal growth cone collapse. J Cell Science 92: 93-100.

Fawcett JW, Montani SM, Brazda N, Müller HW. 2012. Defeating inhibition of regeneration by scar and myelin components. Handb Clin Neurol 109: 503-522.

Fernandez-Klett F, Potas JR, Hilpert D, Blazej K, Radke J, Huck J, Engel O, Stenzel W, Genove G, Priller J. 2013. Early loss of pericytes and perivascular stromal cell-induced scar formation after stroke. J Cereb Blood Flow Metab 33: 428-439.

Fidler PS, Schuette K, Asher RA, Dobbertin A, Thornton SR, Calle-Patino Y, Muir E, Levine JM, Geller HM, Rogers JH, et al. 1999. Comparing astrocytic cell lines that are inhibitory or permissive for axon growth: The major axoninhibitory proteoglycan is NG2. J Neurosci 19: $8778-$ 8788.

Filous AR, Miller JH, Coulson-Thomas YM, Horn KP, Alilain WJ, Silver J. 2010. Immature astrocytes promote CNS axonal regeneration when combined with chondroitinase ABC. Dev Neurobiol 70: 826-841.

Filous AR, Evans TA, Lang BT, Levine J, Bai L, Miller RH, Silver J. 2012. Dystrophic axons form synapse-like connections on $\mathrm{NG}_{2}^{+}$cells after spinal cord injury. Abstr Soc Neurosci 47.13/E11.

Fisher D, Xing B, Dill J, Li H, Hoang HH, Zhao Z, Yang XL, Bachoo R, Cannon S, Longo FM, et al. 2011. Leukocyte common antigen-related phosphatase is a functional receptor for chondroitin sulfate proteoglycan axon growth inhibitors. J Neurosci 31: 14051-14066.

Fitch MT, Silver J. 1997. Activated macrophages and the blood-brain barrier: Inflammation after CNS injury leads to increases in putative inhibitory molecules. Exp Neurol 148: 587-603.
Freund P, Schmidlin E, Wannier T, Bloch J, Mir A, Schwab ME, Rouiller EM. 2006. Nogo-A-specific antibody treatment enhances sprouting and functional recovery after cervical lesion in adult primates. Nat Med 12: 790-792.

Freund P, Schmidlin E, Wannier T, Bloch J, Mir A, Schwab ME, Rouiller EM. 2009. Anti-Nogo-A antibody treatment promotes recovery of manual dexterity after unilateral cervical lesion in adult primates-Re-examination and extension of behavioral data. Eur J Neurosci 29: 983-996.

García-Alías G, Petrosyan HA, Schnell L, Horner PJ, Bowers WJ, Mendell LM, Fawcett JW, Avranian VL. 2011. Chondroitinase $A B C$ combined with neurotrophin NT-3 secretion and NR2D expression promotes axonal plasticity and functional recovery in rats with lateral hemisection of the spinal cord. J Neurosci 31: 17788-17799.

Gensel JC, Nakamura S, Guan Z, van Rooijen N, Ankeny DP, Popovich PG. 2009. Macrophages promote axon regeneration with concurrent neurotoxicity. J Neurosci 29: 3956-3968.

Giger RJ, Hollis ER 2nd, Tuszynski MH. 2010. Guidance molecules in axon regeneration. Cold Spring Harb Perspect Biol 2: a001867.

Ginhoux F, Greter M, Leboeuf M, Nandi S, See P, Gokhan S, Mehler MF, Conway SJ, Ng LG, Stanley ER, et al. 2010. Fate mapping analysis reveals that adult microglia derive from primitive macrophages. Science 330: 841-845.

Giulian D, Robertson C. 1990. Inhibition of mononuclear phagocytes reduces ischemic injury in the spinal cord. Ann Neurol 27: 33-42.

Gogolla N, Caroni P, Lüthi A, Herry C. 2009. Perineuronal nets protect fear memories from erasure. Science 325: $1258-1261$.

Goldshmit Y, Sztal TE, Jusuf PR, Hall TE, Nguyen-Chi M, Currie PD. 2012. Fgf-dependent glial cell bridges facilitate spinal cord regeneration in zebrafish. J Neurosci 32: 7477-7492.

Gonzenbach RR, Gasser P, Zorner B, Hochreutener E, Dietz V, Schwab ME. 2010. Nogo-A antibodies and training reduce muscle spasms in spinal cord-injured rats. Ann Neurol 68: 48-57.

Gordon S, Taylor PR. 2005. Monocyte and macrophage heterogeneity. Nat Rev Immunol 5: 953-964.

Göritz C, Dias DO, Tomilin N, Barbacid M, Shupilakov O, Frisén J. 2011. A pericyte origin of spinal cord scar tissue. Science 333: 238-242.

Gris D. 2004. Transient blockade of the CD11d/CD18 integrin reduces secondary damage after spinal cord injury, improving sensory, autonomic, and motor function. $J$ Neurosci 24: 4043-4051.

Guerrero AR, Uchida K, Nakajima H, Watanabe S, Nakamura M, Johnson WE, Baba H. 2012. Blockade of interleukin-6 signaling inhibits the classic pathway and promotes an alternative pathway of macrophage activation after spinal cord injury in mice. J Neuroinflammation 9: 40.

Guest JD, Hiester ED, Bunge RP. 2005. Demyelination and Schwann cell responses adjacent to injury epicenter cavities following chronic human spinal cord injury. Exp Neurol 192: 384-393. 
J. Silver et al.

Guth L, Zhang Z, DiProspero NA, Joubin K, Fitch MT 1994a. Spinal cord injury in the rat: Treatment with bacterial lipopolysaccharide and indomethacin enhances cellular repair and locomotor function. Exp Neurol 126: 76-87.

Guth L, Zhang Z, Roberts E. 1994b. Key role for pregnenolone in combination therapy that promotes recovery after spinal cord injury. Proc Natl Acad Sci 91: 12308-12312.

Hannila SS, Filbin MT. 2008. The role of cyclic AMP signaling in promoting axonal regeneration after spinal cord injury. Exp Neurol 209: 321-332.

Hansen CN, Fisher LC, Deibert RJ, Jakeman LB, Zhang H, Noble-Haeusslein L, White S, Basso DM. 2013. Elevated $\mathrm{mmp}-9$ in the lumbar cord early after thoracic spinal cord injury impedes motor relearning in mice. J Neurosci 33: 13101-13111.

Herrmann JE, Imura T, Song B, Qi J, Ao Y, Nguyen TK, Korsak RA, Takeda K, Akira S, Sofroniew MV. 2008 STAT3 is a critical regulator of astrogliosis and scar formation after spinal cord injury. J Neurosci 28: 72317243.

Hickman SE, Kingery ND, Ohsumi TK, Borowsky ML, Wang L-C, Means TK, Khoury JE. 2013. The microglial sensome revealed by direct RNA sequencing. Nat Neurosci 16: 1896-1905

Hines DJ, Hines RM, Mulligan SJ, Macvicar BA. 2009. Microglia processes block the spread of damage in the brain and require functional chloride channels. Glia 57: 1610 1618.

Hockfield S, Kalb RG, Zaremba S, Fryer H. 1990. Expression of neural proteoglycans correlates with the acquisition of mature neuronal properties in the mammalian brain. Cold Spring Harb Symp Quant Biol 55: 505-514.

Hollis E 2nd, Tuszynski M. 2011. Neurotrophins: Potential therapeutic tools for the treatment of spinal cord injury. Neurotherapeutics 8: 694-703.

Horn KP, Busch SA, Hawthorne AL, van Rooijen N, Silver J. 2008. Another barrier to regeneration in the CNS: Activated macrophages induce extensive retraction of dystrophic axons through direct physical interactions. J Neurosci 28: 9330-9341.

Iannotti CA, Clark M, Horn KP, van Rooijen N, Silver J, Steinmetz MP. 2011. A combination immunomodulatory treatment promotes neuroprotection and locomotor recovery after contusion SCI. Exp Neurol 230: 3-15.

Johansson CB, Momma S, Clarke DL, Risling M, Lendahl U, Frisén J. 1999. Identification of a neural stem cell in the adult mammalian central nervous system. Cell 96:25-34.

Jones LAT, Lammertse DP, Charlifue SB, Kirshblum SC Apple DF, Ragnarsson KT, Poonian D, Betz RR, Knoller N, Heary RF, et al. 2010. A phase 2 autologous cellular therapy trial in patients with acute, complete spinal cord injury: Pragmatics, recruitment, and demographics. Spinal Cord 48: 798-807.

Joset A, Dodd DA, Halegoua S, Schwab ME. 2010. Pinchergenerated Nogo-A endosomes mediate growth cone collapse and retrograde signaling. J Cell Biol 188: 271-285.

Kadoya K, Tsukada S, Lu P, Coppola G, Geschwind D, Flibin M, Blesch A, Tuszynski MH. 2009. Combined intrinsic and extrinsic neuronal mechanisms facilitate bridging axonal regeneration one year after spinal cord injury. Neuron 29: 165-172.
Kanemaru K, Kubota J, Sekiya H, Hirose K, Okubo Y, Iino M. 2013. Calcium-dependent N-cadherin up-regulation mediates reactive astrogliosis and neuroprotection after brain injury. Proc Natl Acad Sci 110: 11612-11617.

Karnezis T, Mandemakers W, McQualter JL, Zheng B, Ho PP, Jordan KA, Murray BM, Barres B, Tessier-Lavigne M, Bernard CCA. 2004. The neurite outgrowth inhibitor Nogo A is involved in autoimmune-mediated demyelination. Nat Neurosci 7: 736-744.

Kawano H, Kimura-Kurode J, Komuta Y, Yoshioka N, Li HP, Kawamura K, Li Y, Raisman G. 2012. Role of the lesion scar in the response to damage and repair of the central nervous system. Cell Tissue Res 349: 169-180.

Keirstead HS, Hasan SJ, Muir GD, Steeves JD. 1992. Suppression of the onset of myelination extends the permissive period for the functional repair of embryonic spinal cord. Proc Natl Acad Sci 89: 11664-11668.

Kempf A, Montani L, Petrinovic MM, Schroeter A, Weinmann O, Patrignani A, Schwab ME. 2013. Upregulation of axon guidance molecules in the adult central nervous system of Nogo-A knockout mice restricts neuronal growth and regeneration. Eur J Neurosci 38: 3567-3579.

Kempf A, Tews B, Arzt ME, Weinmann O, Obermair FJ, Pernet V, Zagrebelsky M, Delekate A, Iobbi C, Zemmar A, et al. 2014. The sphingolipid receptor S1PR2 is a receptor for Nogo-A repressing synaptic plasticity. PLoS Biol 12: e1001763.

Kigerl K, Popovich P. 2006 Drug evaluation: ProCord-A potential cell-based therapy for spinal cord injury. IDrugs 9: 354-360.

Kigerl KA, Gensel JC, Ankeny DP, Alexander JK, Donnelly DJ, Popovich PG. 2009. Identification of two distinct macrophage subsets with divergent effects causing either neurotoxicity or regeneration in the injured mouse spinal cord. J Neurosci 28: 13435-13444.

Kuo HS, Tsai MJ, Huang MC, Chiu CW, Tsai CY, Lee MJ, Huang WC, Lin YL, Kuo WC, Cheng H. 2011. Acid fibroblast growth factor and peripheral nerve grafts regulate Th2 cytokine expression, macrophage activation, polyamine synthesis, and neurotrophin expression in transected rat spinal cords. J Neurosci 31: 4137-4147.

Kwok JC, Dick G, Wang D, Fawcett JW. 2011. Extracellular matrix and perineuronal nets in CNS repair. Dev Neurobiol 71: 1073-1089.

Kwon BK, Liu J, Messerer C, Kobayashi NR, McGraw J, Oschipok L, Tetzlaff W. 2002. Survival and regeneration of rubrospinal neurons 1 year after spinal cord injury. Proc Natl Acad Sci 99: 3246-3251.

Lalancette-Hébert M, Gowing G, Simard A, Weng YC, Kriz J. 2007. Selective ablation of proliferating microglial cells exacerbates ischemic injury in the brain. J Neurosci $\mathbf{2 7}$ : 2596-2605.

Lammertse DP, Jones LAT, Charlifue SB, Kirshblum SC, Apple DF, Ragnarsson KT, Falci SP, Heary RF, Choudhri TF, Jenkins AL, et al. 2012. Autologous incubated macrophage therapy in acute, complete spinal cord injury: Results of the phase 2 randomized controlled multicenter trial. 50: 661-671.

Lang BT, Cregg JM, Deparul MA, Filous AR, Evans TA, Weng YL, Huang AY, Li S, Silver J. 2012. Peptide inhibitors of LAR family phosphatases release CSPG mediated entrapment of axons and promote robust behavioral recovery 
following contusive spinal cord injury. Abstr Soc Neurosci 252.07/M6.

Lang BT, Cregg JM, Depaul MA, Filous AR, Tran AP, Li S, Evans TA, Busch SA, Silver J. 2013. Non-invasive systemic modulation of the CSPG receptor PTP sigma promotes locomotor and urinary recovery following severe contusive spinal cord injury. Abstr Soc Neurosci 148.03/P13.

Lee JK, Chow R, Xie F, Chow SY, Tolentino KE, Zheng B. 2010. Combined genetic attenuation of myelin and semaphorin-mediated growth inhibition is insufficient to promote serotonergic axon regeneration. J Neurosci 30: 10899-10904.

Lee SM, Rosen S, Weinstein P, van Rooijen N, Noble-Haeusslein LJ. 2011. Prevention of both neutrophil and monocyte recruitment promotes recovery after spinal cord injury. J Neurotrauma 28: 1893-1907.

Lee Y-S, Lin C-Y, Jiang HH, Depaul M, Lin VW, Silver J. 2013. Nerve regeneration restores supraspinal control of bladder function after complete spinal cord injury. J Neurosci 33: 10591-10606.

Levine JM. 1994. Increased expression of the NG2 chondroitin-sulfate proteoglycan after brain injury. J Neurosci 14: 4716-4730.

Li Y, Raisman G. 1995. Sprouts from cut corticospinal axons persist in the presence of astrocytic scarring in long-term lesions of the adult rat spinal cord. Exp Neurol 134: 102 111.

Li H-P, Komuta Y, Kimura-Kuroda J, van Kuppevelt TH, Kawano H. 2013. Roles of chondroitin sulfate and dermatan sulfate in the formation of a lesion scar and axonal regeneration after traumatic injury of the mouse brain. $J$ Neurotrauma 30: 413-425.

Liebscher T, Schnell L, Schnell D, Scholl J, Schneider R, Gullo M, Fouad K, Mir A, Rausch M, Kindler D, et al. 2005. Nogo-A antibody improves regeneration and locomotion of spinal cord-injured rats. Ann Neurol 58: 706719.

Lin SC, Huck JH, Roberts JD, Macklin WB, Somogyi P, Bergles DE. 2005. Climbing fiber innervation of NG2expressing glia in the mammalian cerebellum. Neuron 46: $773-785$.

Lindau NT, Bänninger BJ, Gullo M, Good NA, Bachmann LC, Starkey LM, Schwab ME. 2013. Rewiring of the corticospinal tract in the adult rat after unilateral stroke and anti-Nogo-A therapy. Brain 137: 739-756.

Liu BP, Cafferty WB, Budel SO, Strittmatter SM. 2006a. Extracellular regulators of axonal growth in the adult central nervous system. Philos Trans R Soc Lond B Biol Sci 361: 1593-1610.

Liu X, Hawkes E, Ishimaru T, Tran T, Sretavan DW. 2006b. EphB3: An endogenous mediator of adult axonal plasticity and regrowth after CNS injury. J Neurosci 26: $3087-$ 3101.

Liu K, Tedeschi A, Park KK, He Z. 2011. Neuronal intrinsic mechanisms of axon regeneration. Ann Rev Neurosci 34: $131-152$.

Liuzzi FJ, Lasek RJ. 1987. Astrocytes block axonal regeneration in mammals by activating the physiological stop pathway. Science 237: 642-645.

London A, Cohen M, Schwartz M. 2013. Microglia and monocyte-derived macrophages: Functionally distinct populations that act in concert in CNS plasticity and repair. Front Cell Neurosci 7: 34.

Longbrake EE, Lai W, Ankeny DP, Popovich PG. 2007. Characterization and modeling of monocyte-derived macrophages after spinal cord injury. J Neurochem 102: $1083-$ 1094.

Lutz AB, Barres BA. 2014. Contrasting the glial response to axon injury in the central and peripheral nervous systems. Dev Cell 28: 7-17.

Lytle JM, Vicini S, Wrathall JR. 2006. Phenotypic changes in $\mathrm{NG}^{+}$cells after spinal cord injury. J Neurotrauma 23: $1726-1738$.

Macaya DJ, Hayakawa K, Arai K, Spector M. 2013. Astrocyte infiltration into injectable collagen-based hydrogels containing FGF-2 to treat spinal cord injury. Biomaterials 34: 3591-3602.

Massey JM, Hubscher CH, Wagoner MR, Decker JA, Amps J, Silver J, Onifer SM. 2006. Chondroitinase ABC digestion of the perineuronal net promotes functional collateral sprouting in the cuneate nucleus after cervical spinal cord injury. J Neurosci 26: 4406-4414.

McGee AW, Yang Y, Fischer QS, Daw NW, Strittmatter SM. 2006. Experience-driven plasticity of visual cortex limited by myelin and Nogo receptor. Science 309: 2222-2226.

McKeon RJ, Schreiber RC, Rudge JS, Silver J. 1991. Reduction of neurite outgrowth in a model of glial scarring following CNS injury is correlated with the expression of axon inhibitory molecules on reactive astrocytes. $J$ Neurosci 11: 3398-3411.

McKeon RJ, Hoke A, Silver J. 1995. Injury induced proteoglycans inhibit the potential for laminin mediated axon growth on astrocytic scars. Exp Neurol 136: 32-43.

McKeon RJ, Jurynec MJ, Buck CR. 1999. The chondroitin sulfate proteoglycans neurocan and phosphacan are expressed by reactive astrocytes in the chronic glial scar. $J$ Neurosci 19: 10778-10788.

Mckillop WM, Dragan M, Schedl A, Brown A. 2013. Conditional Sox9 ablation reduces chondroitin sulfate proteoglycan levels and improves motor function after spinal cord injury. Glia 61: 164-177.

McTigue DM, Tripathi R, Wei P. 2006. NG2 colocalizes with axons and is expressed by a mixed cell population in spinal cord lesions. J Neuropathol Exp Neurol 65: 406420.

Meletis K, Barnabé-Heider F, Carlén M, Evergren E, Tomilin N, Shupliakov O, Frisén J. 2008. Spinal cord injury reveals multilineage differentiation of ependymal cells. PLoS Biol 6: e182.

Miron VE, Boyd A, Zhao J-W, Yuen TJ, Ruckh JM, Shadrach JL, van Wijngaarden P, Wagers AJ, Williams A, Franklin RJM, et al. 2013. M2 microglia and macrophages drive oligodendrocyte differentiation during CNS remyelination. Nat Neurosci 16: 1211-1218.

Mokarram N, Merchant A, Mukhatyar V, Patel G, Bellamkonda RV. 2012. Effect of modulating macrophage phenotype on peripheral nerve repair. Biomaterials 33: 8793-8801.

Muller A, Hauk TG, Fischer D. 2007. Astrocyte-derived CNTF switches mature RGCs to a regenerative state following inflammatory stimulation. Brain 130: 3308 3320. 
J. Silver et al.

Nash M, Pribiag H, Fournier AE, Jacobson C. 2009. Central nervous system regeneration inhibitors and their intracellular substrates. Mol Neurobiol 40: 224-235.

Nielson JL, Sears-Kraxberger I, Strong MK, Wong JK, Willenberg R, Steward O. 2010. Unexpected survival of neurons of origin of the pyramidal tract after spinal cord injury. J Neurosci 30: 11516-11528.

Park KK, Liu K, Hu Y, Kanter JL, He Z. 2010. PTEN/mTOR and axon regeneration. Exp Neurol 223: 45-50.

Pekny M, Johansson CB, Eliasson C, Stakeberg J, Wallem A, Perlmann T, Lendahl U, Betsholtz C, berthold CH, Frisen J. 1999. Abnormal reaction to central nervous system injury in mice lacking glial fibrillary acidic protein and vimentin. J Cell Biol 145: 503-514.

Peng X, Kim J, Zhou Z, Fink DJ, Mata M. 2011. Neuronal Nogo-A regulates glutamate receptor subunit expression in hippocampal neurons. J Neurochem 119: 1183-1193.

Pernet V, Schwab ME. 2012. The role of Nogo-A in axonal plasticity, regrowth and repair. Cell Tissue Res 349: 97 104.

Petratos S, Ozturk E, Azari MF, Kenny R, Young Lee J, Magee KA, Harvey AR, McDonald C, Taghian K, Moussa L, et al. 2012. Limiting multiple sclerosis related axonopathy by blocking Nogo receptor and CRMP-2 phosphorylation. Brain 135: 1794-1818.

Phokeo V, Kwiecien JM, Ball AK. 2002. Characterization of the optic nerve and retinal ganglion cell layer in the dysmyelinated adult Long Evans Shaker rat: Evidence for axonal sprouting. J Comp Neurol 451: 213-224.

Pineau I, Sun L, Bastien D, Lacroix S. 2010. Astrocytes initiate inflammation in the injured mouse spinal cord by promoting the entry of neutrophils and inflammatory monocytes in an IL-1 receptor/MyD88-dependent fashion. Brain Behav Immun 24: 540-553.

Pizzorusso T, Medini P, Landi S, Baldini S, Berardi N, Maffei L. 2006. Structural and functional recovery from early monocular deprivation in adult rats. Proc Natl Acad Sci 103: $8517-8522$.

Popovich PG, Hickey WF. 2001. Bone marrow chimeric rats reveal the unique distribution of resident and recruited macrophages in the contused rat spinal cord. J Neuropathol Exp Neurol 60: 676-685.

Popovich PG, Longbrake EE. 2008. Can the immune system be harnessed to repair the CNS? Nat Rev Neurosci 9: 481493.

Popovich PG, Guan Z, Wei P, Huitinga I, Van Rooijen N, Stokes BT. 1999. Depletion of hematogenous macrophages promotes partial hindlimb recovery and neuroanatomical repair after experimental spinal cord injury. Exp Neurol 158: 351-365.

Prewitt CM, Niesman IR, Kane CJ, Houlé JD. 1997. Activated macrophage/microglial cells can promote the regeneration of sensory axons into the injured spinal cord. Exp Neurol 148: 433-443.

Prinz M, Priller J, Sisodia SS, Ransohoff RM. 2011. Heterogeneity of CNS myeloid cells and their roles in neurodegeneration. Nat Neurosci 13: 1227-1235.

Rabchevsky AG, Streit WJ. 1997. Grafting of cultured microglial cells into the lesioned spinal cord of adult rats enhances neurite outgrowth. J Neurosci Res 47: 34-48.
Ramón y Cajal S. 1928. Degeneration and regeneration of the nervous system. Oxford University Press, New York.

Ramón y Cajal S, de Felipe J, Jones EG. 1991. Cajal's degeneration and regeneration of the nervous system, pp. 1-769. Oxford University Press, New York (original published in 1928).

Rapalino O, Lazarov-Spiegler O, Agranov E, Velan GJ, Yoles E, Fraidakis M, Solomon A, Gepstein R, Katz A, Belkin M, et al. 1998. Implantation of stimulated homologous macrophages results in partial recovery of paraplegic rats. Nat Med 4: 814-821.

Reh T, Kalil K. 1982. Functional role of regrowing pyramidal tract fibers. J Comp Neurol 211: 276-283.

Renault-Mihara F, Katoh H, Ikegami T, Iwanami A, Mukaino M, Yasuda A, Nori S, Mabuchi Y, Tada H, Shibata S, et al. 2011. Beneficial copaction of spinal cord lesion by migrating astyrocytes through glycogen synthase kinase3 inhibition. EMBO Mol Med 3: 682-686.

Rudge J, Silver J, 1990. Inhibition of neurite outgrowth on astroglial scars in vitro. J Neurosci 10: 3594-3603.

Ruschel J, Hellal F, Flynn K, Bradke F. 2013. Systenic administration of epothilone $\mathrm{B}$ promotes axon regeneration and functional recovery after spinal cord injury. Abstr Soc Neurosci 148.11.

Sabelström H, Stenudd M, Frisén J. 2013. Neural stem cells in the adult spinal cord. Exp Neurol 260C: 44-49.

Saiwai H, Kumamaru H, Ohkawa Y, Kubota K, Kobayakawa K, Yamada H, Yokomizo T, Iwamoto Y, Okada S. 2013. Ly6C ${ }^{+}$Ly6G-Myeloid-derived suppressor cells play a critical role in the resolution of acute inflammation and the subsequent tissue repair process after spinal cord injury. J Neurochem 125: 74-88.

Sandvig A, Berry M, Barrett LB, Butt A, Logan A. 2004. Myelin-, reactive glia-, and scar-derived CNS axon growth inhibitors: Expression, receptor signaling, and correlation with axon regeneration. Glia 46: 225-251.

Schachtrup C, Ryu JK, Helmrick MJ, Vagena E, Galanakis DK, Degen JL, Margolis RU, Akassoglou K. 2010. Fibrinogen triggers astrocyte scar formation by promoting the availability of active TGF- $\beta$ after vascular damage. J Neurosci 30: 5843-5854.

Schulz C, Perdiguero EG, Chorro L, Szabo-Rogers H, Cagnard N, Kierdorf K, Prinz M, Wu B, Jacobsen SEW, Pollard JW, et al. 2012. A lineage of myeloid cells independent of Myb and hematopoietic stem cells. Science 336: $86-90$.

Schwab ME. 2004. Nogo and axon regeneration. Curr Opin Neurobiol 14: 118-124.

Schwab ME. 2010. Functions of Nogo proteins and their receptors in the nervous system. Nat Rev Neurosci 11: $799-811$.

Schwab ME, Caroni P. 1988. Oligodendrocytes and CNS myelin are nonpermissive substrates for neurite growth and fibroblast spreading in vitro. J Neurosci 8: $2381-$ 2393.

Schwab ME, Thoenen H. 1985. Dissociated neurons regenerate into sciatic but not optic nerve explants in culture irrespective of neurotrophic factors. J Neurosci 5: 24152423.

Shechter R, London A, Varol C, Raposo C, Cusimano M, Yovel G, Rolls A, Mack M, Pluchino S, Martino G, et al. 
2009. Infiltrating blood-derived macrophages are vital cells playing an anti-inflammatory role in recovery from spinal cord injury in mice. PLoS Med 6: e1000113.

Shen Y, Tenney AP, Busch SA, Horn KP, Cuascut FX, Liu K, He Z, Silver J, Flanagan JG. 2009. PTP $\sigma$ is a receptor for chondroitin sulfate proteoglycan, an inhibitor of neural regeneration. Science 326: 592-596.

Silver J, Miller J. 2004. Regeneration beyond the glial scar. Nat Rev Neurosci 5: 146-156.

Silver J, Ogawa MY. 1983. Postnatally induced formation of the corpus callosum in acallosal mice on glial coated cellulose bridges. Science 202: 1067-1069.

Silver DJ, Silver J. 2014. Contributions of chondroitin sulfate proteoglycans to neurodevelopment, injury and cancer. Curr Opin Neurobiol 27: 171-178.

Silver DJ, Steindler DA. 2009. Common astrocytic programs during brain development, injury and cancer. Trends Neurosci 32: 303-311.

Silver J, Lorenz SE, Wahlsten D, Coughlin J. 1982. Axonal guidance during development of the great cerebral commissures: Descriptive and experimental studies, in vivo, on the role of preformed glial pathways. J Comp Neurol 210: $10-29$.

Silver J, Edwards M, Levitt P. 1993. Immunocytochemical demonstration of specialized astroglial structures that form boundaries and pathways along axon tracts in the fetal brain. J Comp Neurol 328: 415-436.

Singer M, Nordlander RH, Egar M. 1979. Axonal guidance during embryogenesis and regeneration in the spinal cord of newt: The blueprint hypothesis of neuronal pathway patterning. J Comp Neurol 185: 1-22.

Sobel RA, Chen M, Maeda A, Hinojoza JR. 1995. Vitronectin and integrin vitronectin receptor localization in multiple sclerosis lesions. J Neuropathol Exp Neurol 54: $202-$ 213.

Soderblom C, Luo X, Blumenthal E, Bray E, Lyapichev K, Ramos J, Krishnan V, Lai-Hsu C, Park KK, Tsoulfas P, et al. 2013. Perivascular fibroblasts form the fibrotic scar after contusive spinal cord injury. J Neurosci 33: 13882-13887.

Steinmetz MP, Horn KP, Tom VJ, Miller JH, Busch SA, Nair D, Silver DJ, Silver J. 2005. Chronic enhancement of the intrinsic growth capacity of sensory neurons combined with the degradation of inhibitory proteoglycans allows functional regeneration of sensory axons through the dorsal root entry zone in the mammalian spinal cord. $J$ Neurosci 25: 8066-8076.

Stichel CC, Hermanns S, Luhmann HJ, Lausberg F, Niermann H, D’Urso D, Servos G, Hartwig HG, Muller HW. 1999. Inhibition of collagen IV deposition promotes regeneration of injured CNS axons. Eur J Neurosci 11: 632646.

Stout RD, Jiang C, Matta B, Tietzel I, Watkins SK, Suttles J. 2005. Macrophages sequentially change their functional phenotype in response to changes in microenvironmental influences. J Immunol 175: 342-349.

Sun F, Park KK, Belin S, Wang D, Lu T, Chen G, Zhang K, Yeung C, Feng G, Yankner BA, et al. 2011. Sustained axon regeneration induced by co-deletion of PTEN and SOCS3. Nature 480: 372-375.
Swirski FK, Nahrendorf M, Etzrodt M, Wildgruber M, Cortez-Retamozo V, Panizzi P, Figueiredo J-L, Kohler RH, Chudnovskiy A, Waterman P, et al. 2009. Identification of splenic reservoir monocytes and their deployment to inflammatory sites. Science 325: 612-616.

Takeuchi K, Onaga SH, Watanabe Y, Kudo C, Ohko K, Sato T, Oda K, Yokoyama M, Yoshioka N, Sakimura K, et al. 2013. Chondroitin sulphate $N$-acetylgalactosaminyltransferase-1 inhibits recovery from neural injury. Nat Commun 4: 2740.

Tan AM, Colletti M, Rorai AT, Skene JH, Levine JM. 2006. Antobidies against the NG2 proteoglycan promote the regeneration of sensory axons within the dorsal columns of the spinal cord. J Neurosci 26: 4729-4739.

Tang S, Shen YJ, DeBellard ME, Mukhopadhyay G, Salzer JL, Crocker PR, Filbin MT. 1997. Myelin-associated glycoprotein interacts with neurons via a sialic acid binding site at ARG118 and a distinct neurite inhibition site. J Cell Biol 138: 1355-1366.

Tansey EM, Pessoa VF, Fleming S, Landon DN, Ikeda H. 1985. Pattern and extent of demyelination in the optic nerves of mice infected with Semliki forest virus and the possibility of axonal sprouting. Brain 108: 29-41.

Thawer SG, Mawhinney L, Chadwick K, de Chickera SN, Weaver LC, Brown A, Dekaban GA. 2013. Temporal changes in monocyte and macrophage subsets and microglial macrophages following spinal cord injury in the Lys-Egfp-ki mouse model. J Neuroimmunol 261: 7-20.

Tsai SY, Papadopoulos CM, Schwab ME, Kartje GL. 2011. Delayed anti-Nogo-A therapy improves function after chronic stroke in adult rats. Stroke 42: 186-190.

Wang D, Fawcett J. 2012. The perineuronal net and the control of CNS plasticity. Cell Tissue Res 349: 147-160.

Wanner IB, Anderson MA, Song B, Levine J, Fernandez A, Gray-Thompson Z, Ao Y, Sofroniew MV. 2013. Glial scar borders are formed by newly proliferated, elongated astrocytes that interact to corral inflammatory and fibrotic cells via STAT-3 dependent mechanisms after spinal cord injury. J Neurosci 33: 12870-12886.

Wilhelmsson U, Li L, Pekna M, Berthold C-H, Blom S, Eliasson C, Renner O, Bushong E, Ellisman M, Morgan TE, et al. 2004. Absence of glial fibrillary acidin protein and vimentin prevents hypertrophy of astrocytic process and improves post-traumatic regeneration. J Neurosci 24: 5016-5021.

Windle WF, Chambers WW. 1950. Regeneration in the spinal cord of the cat and dog. J Comp Neurol 93: 241-257.

Xu K, Messing A, Silver J. 1999. Glial fibrillary acidic protein is necessary for mature astrocytes to react to $\beta$-amyloid substrates in vitro. Glia 25: 390-403.

Xue Y-X, Xue L-F, Liu J-F, He J, Deng J-H, Sun S-C, Han HB, Luo YX, Xu L-Z, Wu P, et al. 2014. Depletion of perineuronal nets in the amygdala to enhance the erasure of drug memories. J Neurosci 34: 6647-6658.

Yamada H, Fredette B, Shitara K, Hagihara K, Miura R, Ranscht B, Stallcup WB, Yamaguchi Y. 1997. The brain chondroitin sulfate proteoglycan brevican associates with astrocytes ensheathing cerebellar glomeruli and inhibits neurite outgrowth from granule neurons. J Neurosci 17: 7784-7795.

Yamaguchi Y. 2000. Lecticans: Organizers of the brain extracellular matrix. Cell Mol Life Sci 57: 276-289. 
J. Silver et al.

Yang Z, Suzuki R, Daniels SB, Brunquell CB, Sala CJ, Nishiyama A. 2006. NG2 glial cells provide a favorable substrate for growing axons. J Neurosci 26: 3829-3839.

Yang Y, Liu Y, Wei P, Peng H, Winger R, Hussain RZ, Ben LH, Cravens PD, Gocke AR, Puttaparthi K, et al. 2010. Silencing Nogo-A promotes functional recovery in demyelinating disease. Ann Neurol 67: 498-507.

Yin Y, Cui Q, Li Y, Irwin N, Fischer D, Harvey AR, Benowitz LI. 2003. Macrophage-derived factors stimulate optic nerve regeneration. J Neurosci 23: 2284-2293.

Yin Y, Henzl MT, Lorber B, Nakazawa T, Thomas TT, Jiang F, Langer R, Benowitz LI. 2006. Oncomodulin is a macrophage-derived signal for axon regeneration in retinal ganglion cells. Nat Neurosci 9: 843-852.

Ylera B, Ertürk A, Hellaf F, Nadrigny F, Hurtado A, Tahirovic S, Oudega M, Kirchhoff F, Bradke F. 2009. Chronically CNS-injured adult sensory neurons gain regenerative competence upon a lesion of their peripheral axon. Curr Biol 19: 930-936.

Zai LJ, Wrathall JR. 2005. Cell proliferation and replacement following contusive spinal cord injury. Glia 50: 247-257.
Zhang Z, Guth L. 1997. Experimental spinal cord injury Wallerian degeneration in the dorsal column is followed by revascularization, glial proliferation, and nerve regeneration. Exp Neurol 147: 159-171.

Zhang Y, Tohyama K, Winterbottom JK, Haque NS, Schahner M, Lieberman AR, Anderson PN. 2001. Correlation between putative inhibitory molecules at the dorsal root entry zone and failure of dorsal root axonal regeneration. Mol Cell Neurosci 17: 444-459.

Zhou L, Baumgartner BJ, Hill-Felberg SJ, McGowen LR, Shine HD. 2003. Neurotrophin-3 expressed in situ induces axonal plasticity in the adult injured spinal cord. J Neurosci 23: 1424-1431.

Zimmer M, Palmer A, Köhler J, Klein R. 2003. EphB-ephrinB bi-directional endocytosis terminates adhesion allowing contact mediated repulsion. Nat Cell Biol 5: 869-878.

Zorner B, Schwab ME. 2010. Anti-Nogo on the go: From animal models to a clinical trial. Ann NY Acad Sci 1198: E22-E34.

Zukor K, Belin S, Wang C, Keelan N, Wang X, He Z. 2013 Short hairpin RNA against PTEN enhances regenerative growth of corticospinal tract axons after spinal cord injury. J Neurosci 33: 15350-15361. 


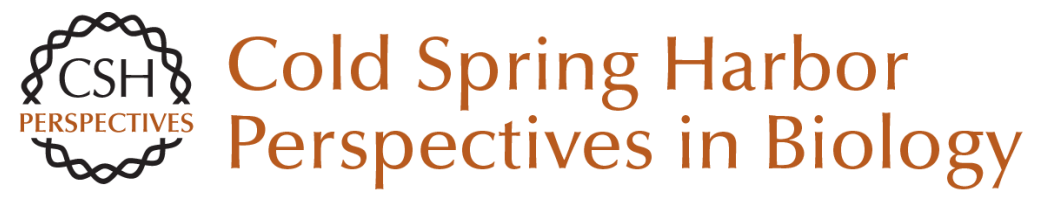

\section{Central Nervous System Regenerative Failure: Role of Oligodendrocytes, Astrocytes, and Microglia}

Jerry Silver, Martin E. Schwab and Phillip G. Popovich

Cold Spring Harb Perspect Biol 2015; doi: 10.1101/cshperspect.a020602 originally published online December 4, 2014

\section{Subject Collection Glia}

The Nodes of Ranvier: Molecular Assembly and Maintenance Matthew N. Rasband and Elior Peles

Microglia in Health and Disease Richard M. Ransohoff and Joseph El Khoury

The Astrocyte: Powerhouse and Recycling Center Bruno Weber and L. Felipe Barros

Microglia Function in Central Nervous System Development and Plasticity Dorothy P. Schafer and Beth Stevens

Transcriptional and Epigenetic Regulation of Oligodendrocyte Development and Myelination in the Central Nervous System Ben Emery and Q. Richard Lu

Origin of Microglia: Current Concepts and Past Controversies Florent Ginhoux and Marco Prinz

Glia Disease and Repair--Remyelination Robin J.M. Franklin and Steven A. Goldman

Astrocytes in Neurodegenerative Disease Hemali Phatnani and Tom Maniatis
Oligodendrocyte Development and Plasticity Dwight E. Bergles and William D. Richardson

Oligodendrocytes: Myelination and Axonal Support Mikael Simons and Klaus-Armin Nave

Drosophila Central Nervous System Glia Marc R. Freeman

Perisynaptic Schwann Cells at the Neuromuscular Synapse: Adaptable, Multitasking Glial Cells Chien-Ping Ko and Richard Robitaille

Astrocytes Control Synapse Formation, Function, and Elimination Won-Suk Chung, Nicola J. Allen and Cagla Eroglu

\section{Schwann Cell Myelination} James L. Salzer

Schwann Cells: Development and Role in Nerve Repair Kristján R. Jessen, Rhona Mirsky and Alison C. Lloyd

Perineurial Glia Sarah Kucenas

For additional articles in this collection, see http://cshperspectives.cshlp.org/cgi/collection/

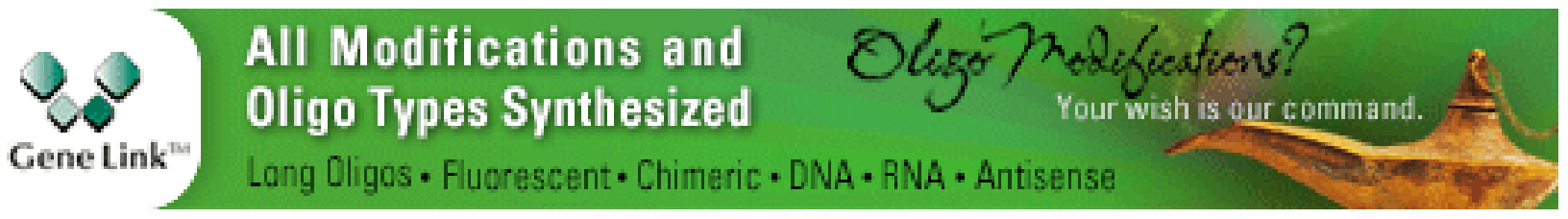

